\title{
Association of perceived environment walkability with purposive and discursive walking for urban design strategies
}

\author{
Hsu-Sheng Hsieh (corresponding author) \\ National Sun Yat-sen University \\ hs.hsieh@mail.nsysu.edu.tw
}

\author{
Min-Ta Chuang \\ University of Taipei \\ chuangminta@utaipei.edu.tw
}

\begin{abstract}
The relationship between the built environment and walking behavior has been explored extensively. However, little research has been done to either differentiate between walking for transport and walking as activity or that applies urban design tools to walkability improvement based on environment-walking associations. Therefore, this study constructed perceived environment walkability factors to replace unidentified physical environments that varied among individuals and examined their associations with walking to a destination (purposive walking) and walking as activity (discursive walking), using factor analysis and structural equation modeling. Results suggest that residential density, land-use mix diversity, and pedestrian/traffic safety were associated with purposive walking while aesthetics and crime safety were associated with discursive walking. Land-use mix access and street connectivity were common correlates of both walking patterns. This study also explored how to apply urban design tools, including land-use plans, zoning control, and urban design guidelines, to shape a walkable environment based on the environment-walking associations.
\end{abstract}

Keywords: Perceived environment walkability, built environment, purposive walking, discursive walking, urban design

\section{Article history:}

Received: August 6, 2020

Received in revised form: April

20, 2021

Accepted: June 11, 2021

Available online: October 15, 2021

\section{Introduction}

Pedestrians are crucial for a vital and attractive urban environment (Jacobs, 1961), and walking as physical activity is associated with travelers' health (Li, Zhao, Zhang, \& Quan, 2019; Longo, Hutchinson, Hunter, Tully, \& Kee, 2015; Sallis, Johnson, Calfas, Caparosa, \& Nichols, 1997). Hence, sustainable urban and transport planning has considered how to shape the built environment facilitating walking (Gase, Barragan, Simon, Jackson, \& Kuo, 2015; Yang, Xu, Rodriguez, Michael, \& Zhang, 2018). In practice, since the development of pedestrian environments often involves both public and private land/space, urban design guidance in spatial development and layout is necessary (Ewing \& Handy, 2009). Clarifying the association between the built environment and walking behavior helps understand what environmental components urban design tools should regulate and shape.

To unveil the environment-walking association, previous studies (Kaczynski et al., 2018; Tian

Copyright 2021 Hsu-Sheng Hsieh \& Min-Ta Chuang

http://dx.doi.org/10.5198/jtlu.2021.1869

ISSN: 1938-7849 | Licensed under the Creative Commons Attribution - Noncommercial License 4.0

The Journal of Transport and Land Use is the official journal of the World Society for Transport and Land Use (WSTLUR) and is published and sponsored by the University of Minnesota Center for Transportation Studies. 
\& Ewing, 2017) have adopted objective street quality attributes to investigate walking behavior and improve the four-step transport model that uses socio-economic and land-use variables (ITE, 2017) to predict walk trips. However, it is impracticable for constructing individual models to collect the actual "objective street quality attributes" of all individuals who have different daily activity areas, even living in the same neighborhood. Thus, most walk trip generation models only incorporated the macro environment such as zonal population and employment density (Habib, Han, \& Lin, 2014) or average objective street quality attributes in the road-network area, which is, however, inconsistent with individual actual daily activity areas (Tian \& Ewing, 2017). To bridge the gap, perceived environment walkability (PEW), which plays a mediator between individual objective environment and walking generation (Ewing \& Handy, 2009) as psychological reactions to the environment, could be substituted for objective environment walkability, despite that researchers do not capture the objective environment areas. Since PEW is derived from perceptions of the physical features of the environment, it may be more proximal predictors of individual walking behavior than physical features. Also, PEW as individual perception focuses on street quality surrounding individual daily life and thereby complements macro land-use variables explaining walking behavior. Hence, understanding PEW of residents could refine general and walking trip generation models for travel demand forecasting and transport planning.

For the measurement of walkability perceptions, the Neighborhood Environment Walkability Scale (NEWS) can be applied. The NEWS was developed based on the American neighborhood environment for physical activity promotion (Saelens, Sallis, Black, \& Chen, 2003). It has been applied to other Western cities to analyze walking time (Cerin, Saelens, Sallis, \& Frank, 2006) and Japan to explore walking time under different purposes (Inoue et al., 2010) and Hong Kong for walking, loneliness, and happiness research (Yu, Cheung, Lau, \& Woo, 2017). In the NEWS, eight environmental factors surrounding individual perceptions of environmental and street features and sensory experience during walking measure individual subjective walkability, containing residential density, land-use mix diversity, land-use mix access, street connectivity, walking facilities, aesthetics, pedestrian/traffic safety, and crime safety. Many previous studies have supported the association of PEW measured by the NEWS with physical activity (Saelens, Sallis, Black, et al., 2003) and walking time (Cerin et al., 2006; Inoue et al., 2010; Yu et al., 2017).

However, a research gap has emerged as a limited identification of walking behavior in quantitative investigations applying the NEWS or other PEW scales. Based on the perspective of walking as an active mode of perceiving the urban environment (Winkler, 2002), walking is not only "walking for transport" as discussed in transport literature but also "urban activity" mixed in pedestrian traffic flows. In urban design and mobility literature, Wunderlich (2008) proposes a distinction between purposive walking (utilitarian walking) and discursive walking (a type of discretionary walking). Purposive walking is essential and destination-oriented transport but is practiced by foot with a specific destination such as work, home, a shop, or a park. Therefore, purposive walking longing for arrival entails a rapid and constant pace. Such walking is associated with road networks and destination distribution patterns but not strongly associated with aesthetic sense obtained from urban environments along walking paths (Careri, 2017). Compared to discursive walking, purposive walking tends to be performed in a psychologically anxious mode as people long for arrival at a destination, for example, pacing along with the crowd, rushing through, walking to work, and walking home (Wunderlich, 2008). By contrast, discursive walking is a spontaneous walk characterized by varying pace and relaxing attitudes and has no specific destination when departing or at all (thus also called urban roaming) (Kärrholm, Johansson, Lindelöw, \& Ferreira, 2014; Sarmento, 2016; Wunderlich, 2008). Thus, discursive walking differs from walking to a destination for recreational activity (walking for recreation) because a discursive walk can be treated as the trip purpose of itself. Activity purposes (probably for leisure, recreation, health, or any others) are achieved 
during discursive walking. People who perform discursive walking may half-consciously explore streets and landscapes while sensorially experiencing it passing by (Wunderlich, 2008).

Based on the above distinct characteristics between purposive and discursive walking, it could be presumed that the two types of walking need different spatial features. Clarifying the determinants of the two types of walking may help urban designers understand what components in the built environment should be shaped, as discussed above, and what effects could be achieved. For example, when the objective is to reduce road congestion and promote pedestrian traffic, the use of the setbacks produced from urban design guidelines controlling private land and buildings should include the components facilitating purposive walking. In contrast, when the lively atmosphere in a city area is treated as the target, a land-use plan avoiding single primary use (Jacobs, 1961) with zoning control ensuring the environment encouraging discursive walking should be considered. These urban design tool applications that shape the walking environment depend on understanding the associations between environmental characteristics and specific walking types. Previous transport and land-use research has paid much attention to "walking for transport" (purposive walking), and urban research has done so to qualitatively characterizing "walking as activity" (discursive walking), but, to our knowledge, less has examined the environmental determinants of discursive walking and compared those of discursive and purposive walking.

\subsection{Objectives of the present study}

The identified gap suggested the necessity of the differentiation between walking for transport and walking as activity when exploring environment-walking associations and linking the associations with urban design tools. Therefore, the sequential objectives of this study were (1) to develop PEW factors and measures based on the NEWS to address the difficulty in capturing objective walking environments varying among individuals, (2) to quantify the associations of the measured PEW with purposive and discursive walking, and (3) to present urban design strategies for walkability improvement based on the identified environment-walking associations. This study took the high population-density regions in Taiwan, where pedestrian rights are subordinate to motorized traffic and sidewalks are often occupied by vendors and parked vehicles (Hsieh, 2020), as the case to investigate. The results could provide insights for initially developed countries to improve walkability through urban design tools.

\subsection{Study framework}

This study adapted the factors and measures of NEWS to the study region. Thus, the walkability assessed from the objective environment, which could not be captured when building individual walking models, was converted to individual PEW. Then, to evaluate whether each set of PEW measures reflected their corresponding walkability factor in the empirical region as the NEWS hypothesized, the reliability and validity of factors measured were tested for measurement modification. Factor reliability was confirmed by Cronbach's alpha, calculated based on the average inter-correlation among the measurement results by multiple measures. Its purpose was to confirm whether a factor could be reflected commonly by the measures as hypothesized. Factor validity was examined through factor analysis to extract one common factor (i.e., confirmatory factor analysis, specifying the number of extracted common factors) representing the walkability factor from the measures hypothetically commonly reflecting the factor. In the analysis, relationships between each factor and its hypothetical measures were built by a factor model where the factor explained its measures with weight coefficients (factor loadings), values of which suggested the validity of factor measurement (since the higher a factor loading was, the less the measurement error explained a measure). According to test results based on empirical data, walkability 
factors and measures could be adapted to the study region.

Afterward, the associations between perceived environment walkability factors and walking behavior were examined by structural equation modeling (SEM). This method was used to simultaneously estimate measurement models, reporting the loadings of walkability factors on their measures (whose specifications were based on previous reliability and confirmatory factor analysis), and a structural model, reporting the correlations between walkability factors and walking behavior. All coefficients in measurement and structural models could be simultaneously tested statistically in SEM. Associations of purposive walking and discursive walking with walkability factors were separately estimated. The identified associations were used as bases for presenting urban design strategies to facilitate a walkable environment. The overall framework of this study is illustrated in Fig. 1.

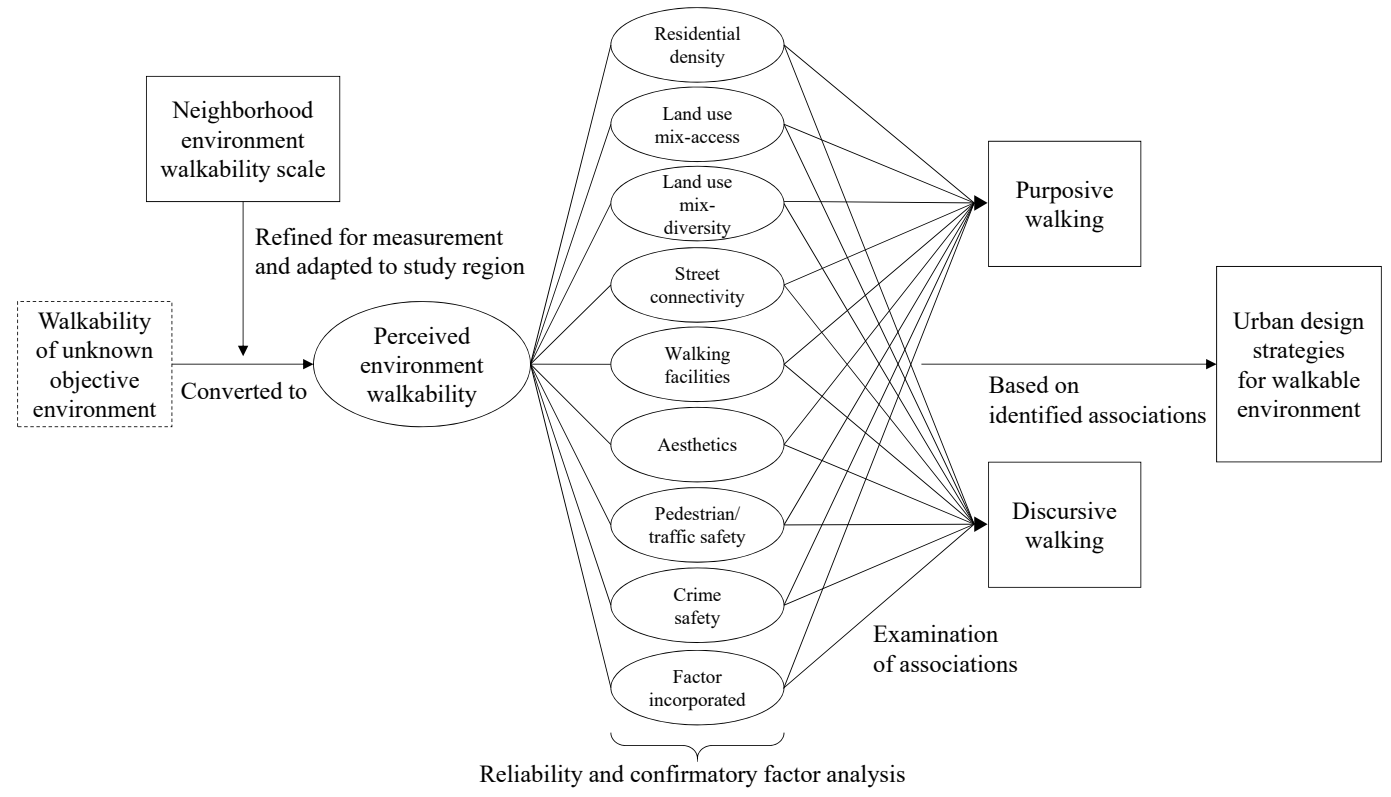

Figure 1. Study framework

\section{$2 \quad$ Literature review}

\subsection{Perceived environment walkability and applications}

Several environment walkability measures have been proposed. A dominant one is the Neighborhood Environment Walkability Scale (NEWS), which captures residents' perceptions of how a neighborhood features travel by foot and cycling. The NEWS was originally developed in the United States and widely applied to assessing American neighborhood environmental factors for several purposes, such as walking promotion, street vitality activation, and community renaissance (Brownson et al., 2004; Saelens, Sallis, Black, et al., 2003; Saelens, Sallis, \& Frank, 2003). Afterward, the NEWS has been used in other western countries, including Belgian (De Bourdeaudhuij, Sallis, \& Saelens, 2003), Canada (Kerr et al., 2006), and Australia (Leslie \& Cerin, 2008). The advantage of NEWS is that it was created based on empirical literature and by a comprehensive group of experts from transport, environmental protection, and urban planning professionals (Saelens, Sallis, \& Frank, 2003). The NEWS contains eight comprehensive environmental factors: (1) residential density, (2) land-use mix diversity, (3) land-use mix access, 
(4) street connectivity, (5) walking facilities, (6) aesthetics, (7) pedestrian/traffic safety, and (8) crime safety. The validity of the measurement of these factors (Cerin et al., 2006) and the correlation between the subjective levels of these factors and whether a neighborhood is objectively assessed as walkable (Cerin, Macfarlane, Ko, \& Chan, 2007) have been supported by empirical evidence.

The NEWS has also been applied to different built environments and development levels to measure residents' PEW (See Table 1). For example, Cerin et al. (2007) confirmed the applicability of the NEWS for residents in Hong Kong to build a set of measures for a highly developed Chinese city (Chinese NEWS) to discuss active transport promotion. Afterward, considering population aging, Yu et al. (2017) extracted nine items from the Chinese NEWS for seniors in Hong Kong and revealed that the wellbeing of the seniors could be enhanced through the improvements of land-use mix access (rather than land-use mix diversity), infrastructure for walking, and traffic safety. Also, for adaptation to locality, a Japanese version of NEWS has been developed (Inoue et al., 2010) and used to capture the association between PEW and walking for errands, leisure, and adults' commuting four Japanese cities (Inoue et al., 2010). Although for these Asian cities, the overall positive correlation between measured walkability and walking behavior corresponds to the studies based on the original NEWS in western countries, differences can be found, e.g., in the negative correlations of high residential density and land-use mix with leisure walking time of Japanese women (Inoue et al., 2010). The differences may indicate that the policy application of PEW results (e.g., walking-oriented land-use plans or urban design guidelines) should depend on locality and target walking behavior. Hence, developing PEW measures from the study environment, instead of using a scale as a priori (e.g., Saelens, Sallis, Black, et al., 2003), is needed to reveal the environment-walking association. 
Table 1. Cases of perceived environment walkability applications

\begin{tabular}{|c|c|c|c|}
\hline $\begin{array}{l}\text { Country and city } \\
\text { (reference) }\end{array}$ & $\begin{array}{l}\text { Number of } \\
\text { samples }\end{array}$ & Main objective & Findings \\
\hline $\begin{array}{l}\text { The State of Califor- } \\
\text { nia, the United States } \\
\text { (Saelens, Sallis, Black, et } \\
\text { al., 2003) }\end{array}$ & 107 & $\begin{array}{l}\text { Survey neighborhood walking } \\
\text { environment (NEWS) and } \\
\text { compare the difference in } \\
\text { health between heterogeneous } \\
\text { groups. }\end{array}$ & $\begin{array}{l}\text { (1) Districts with high neighborhood environment walk- } \\
\text { ability featured high residential density, diverse land-use mix, } \\
\text { high street connectivity, good aesthetics, and safety from the } \\
\text { environment. } \\
\text { (2) Residents had lower obesity prevalence in a district with } \\
\text { high environment walkability. }\end{array}$ \\
\hline $\begin{array}{l}\text { The State of Washington, } \\
\text { the United States (Cerin } \\
\text { et al., 2006) }\end{array}$ & 1,286 & $\begin{array}{l}\text { Develop an abbreviated NEWS } \\
\text { (NEWS-A) for a more compre- } \\
\text { hensive validity. }\end{array}$ & $\begin{array}{l}\text { (1) Land-use mix, residential density, infrastructure for walk- } \\
\text { ing, aesthetics, traffic safety, and safety from crime in the } \\
\text { NEWS-A were positively correlated with walking time for } \\
\text { commuting to work. } \\
\text { (2) Aesthetics, land-use mix, and residential density were } \\
\text { positively correlated with walking time for leisure. }\end{array}$ \\
\hline $\begin{array}{l}\text { Hong Kong, China } \\
\text { (Cerin et al., 2007) }\end{array}$ & 124 & $\begin{array}{l}\text { Present Chinese NEWS-A } \\
\text { applied to Hong Kong for } \\
\text { supporting the availability of } \\
\text { using NEWS for cross-national } \\
\text { studies. }\end{array}$ & $\begin{array}{l}\text { (1) Residents of highly walkable neighborhoods reported } \\
\text { higher scores for residential density, land-use mix, street con- } \\
\text { nectivity, walking facilities, and traffic safety. } \\
\text { (2) Those residents reported lower scores for traffic load and } \\
\text { street obstruction. }\end{array}$ \\
\hline $\begin{array}{l}\text { Hong Kong, China } \\
\text { (Cerin et al., 2010) }\end{array}$ & 484 & $\begin{array}{l}\text { Expand NEWS-A for Chinese } \\
\text { seniors in Hong Kong }\end{array}$ & $\begin{array}{l}\text { (1) The factors of indoor places for walking, presence of people } \\
\text { for being seen and seeking help, crowdedness, crowding, and } \\
\text { social disorder are incorporated. } \\
\text { (2) The factors of physical barriers to walking and traffic speed } \\
\text { are isolated. } \\
\text { (3) This expansion provided abundant environment walkabil- } \\
\text { ity factors considered for seniors. }\end{array}$ \\
\hline $\begin{array}{l}\text { Koganei, Tsukuba, Shi- } \\
\text { zuoka, and Kagoshima, } \\
\text { Japan (Inoue et al., 2010) }\end{array}$ & 1,461 & $\begin{array}{l}\text { Explore the difference in } \\
\text { neighborhood environment } \\
\text { walkability influence on walk- } \\
\text { ing time under different trip } \\
\text { purposes. }\end{array}$ & $\begin{array}{l}\text { (1) High residential density, diverse land-use mix, good infra- } \\
\text { structure for walking, and environmental aesthetics increased } \\
\text { walking time. } \\
\text { (2) Walking time for commuting to work was positively associ- } \\
\text { ated with residential density and land-use mix. } \\
\text { (3) Walking time for leisure was positively associated with } \\
\text { environmental aesthetics and traffic safety. } \\
\text { (4) High residential density and land-use mix could interfere } \\
\text { with leisure walking (time) among women. }\end{array}$ \\
\hline $\begin{array}{l}\text { Hong Kong, China (Yu } \\
\text { et al., 2017) }\end{array}$ & 181 & $\begin{array}{l}\text { Explore the neighborhood } \\
\text { environment walkability and } \\
\text { analyze the correlation between } \\
\text { health and loneliness for the } \\
\text { elderly. }\end{array}$ & $\begin{array}{l}\text { (1) Environment walkability was positively correlated with } \\
\text { walking time. } \\
\text { (2) The residents in the districts with high neighborhood envi- } \\
\text { ronment walkability had higher life satisfaction and happiness. } \\
\text { (3) The residents in the districts with low neighborhood envi- } \\
\text { ronment walkability had higher loneliness. } \\
\text { (4) Diverse land-use mix, good infrastructure for walking, and } \\
\text { traffic safety were positively correlated with health. }\end{array}$ \\
\hline
\end{tabular}




\subsection{Walkability and walk trip generation}

Previous studies have stressed the necessity of the incorporation of the built environment into walk trip generation. For example, Burbidge and Goulias (2009) developed a conceptual model of active travel behavior, containing infrastructure and environment components in addition to psychological factors, demographics, and personal traits. However, the comprehensive environmental determinants of walk trip generation have not been fully identified, especially for those related to the street environment on a neighborhood scale. Empirical studies have partially supplemented such environmental factors influencing walking decisions. For example, Greenwald and Boarnet (2001) found that transit-oriented land use had a positive effect, at the neighborhood level, on nonwork walk trip generation. Habib et al. (2014) presented investigations into walk trip generation based on a large-scale household travel survey. They showed that population density and socio-economic attributes were significant determinants of walk trip generation in an urban region in Canada. Olojede, Yoade, and Olufemi (2017) revealed that trip length negatively affected the walking frequency of travelers in a Nigerian city, implying the importance of short-distance land-use patterns to walk trip generation.

As an important case incorporating the built environment into a walk trip generation model, Tian and Ewing (2017) explored home-based walk trip frequency at the household level in Portland, Oregon, by two-stage modeling. The first stage estimated the probability of whether a household makes any daily walk trips, and the second stage estimated daily walk trip frequency for those households with any daily walk trips. District transit density, intersection density, and sidewalk quality were identified as the factors in making any daily walk trips for households. District land-use entropy positively impacted daily walk trip frequency for those households with any daily walk trips. However, these results might not fully represent how neighborhood environment features influence personal walking behavior because of (1) using household-level travel data and (2) treating the built environments of different agents (households) in an analyzed buffer as the same. Using individual travel data and incorporating individual perceptions of the built environment that belongs to their respective daily activity area could address the two issues. As shown in Fig. 2, ignoring individual reactions to physical features in the built environment might lose the link between physical features and walking behavior when each individual's physical features cannot be captured. Therefore, applying PEW could facilitate the understanding of the influence of the built environment on walking behavior. 


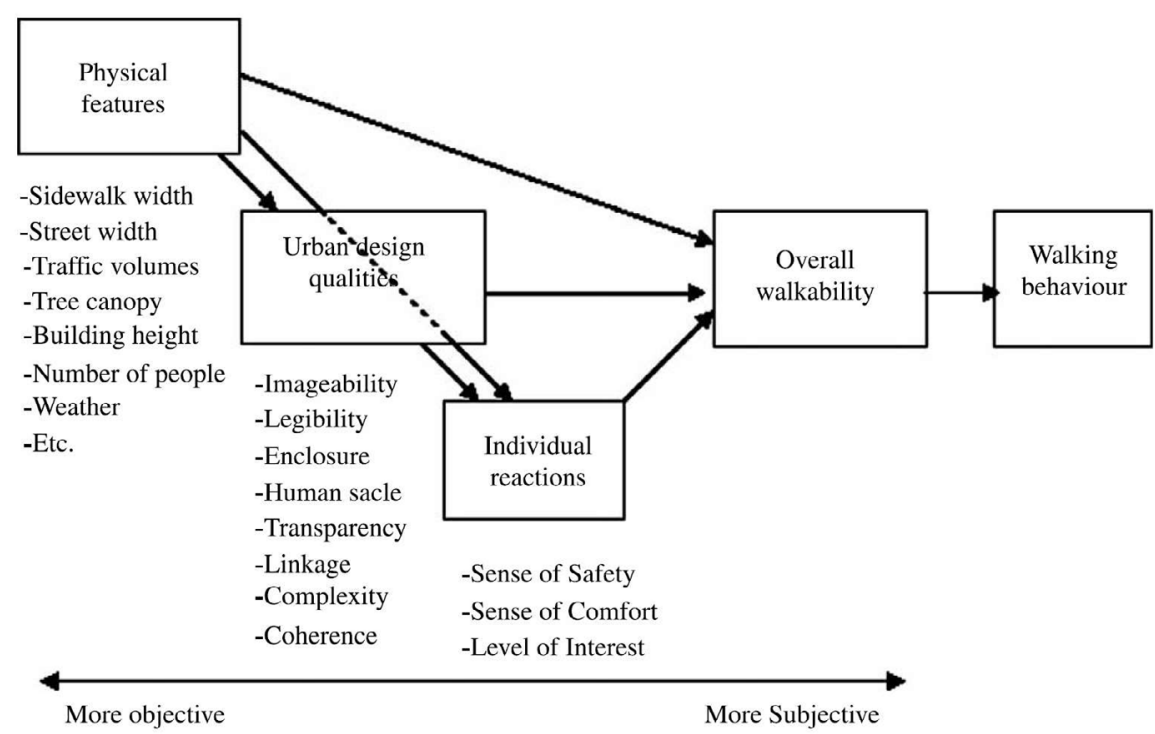

Figure 2. Proximal role of individual reactions to physical features in walkability and walking (Ewing \& Handy, 2009)

\subsection{Investigations of walking environment and behavior in Taiwan}

Influenced by sustainable development perspectives, transport research interests in Taiwan have increasingly paid attention to walking transport and its determinants. For example, Chang and Shen (2005) clarified the cognitive indicators of an intention to walk of residents, including attitudes towards walking and leisure, pro-social personality, and satisfaction towards walking environments in addition to trip characteristics. Tung (2005) focused on the built environment surrounding a pedestrian mall and found by an interview that tourists and visitors chose their walking paths according to the signposts for pedestrians, connectivity to activity locations, and commercial density. Chiang and Weng (2012) applied the abbreviated NEWS (NEWS-A) and suggested that accessibility, walking infrastructure, landscape aesthetics, and street connectivity were associated with walking behavior. However, the study only addressed the overall walking behavior without separating walking types, which may moderate the influence of the built environment on walking behavior.

Through the above review, this study argued that introducing PEW, adapting its factors and measures to the study environment, and distinguishing walking behavior types may help understand the association of the built environment and walking behavior.

\section{$3 \quad$ Methods}

\subsection{Data collection and respondents}

For revealing the association between PEW and walking behavior in Taiwan, this study constructed PEW factors from residents' perceptions of the built environment. Therefore, residents across counties/ 
cities were face-to-face interviewed by trained interviewers who have completed a semester of an undergraduate course about questionnaire survey and interview methods. Pedestrians on the streets were invited in the city/town centers in Northern, Central, and Southern Taiwan, but Eastern Taiwan with relatively low population density $\left(<100\right.$ inhabitants $\left./ \mathrm{km}^{2}\right)$ and offshore islands with distinctive development were excluded (see Fig. 3). Systematic sampling was adopted so that every second pedestrian who passed the interviewer was invited. By excluding the pedestrians who lived outside the county/city, interviewers asked the residents questions and filled an electronic questionnaire. The survey proceeded from Jan 5 to Jan 19, 2019, and collected answers from 876 residents. The individual data of the following aspects were obtained: (1) individual demographics and travel characteristics for understanding the composition of respondents, (2) individual perceptions measured by the revised NEWS for constructing PEW factors (see 3.2. Variables and measurement), and (3) individual purposive and discursive walking frequency and duration for examining environment-walking association. The respondents with any missing answers were eliminated from the dataset, resulting in 399 valid respondents.

453

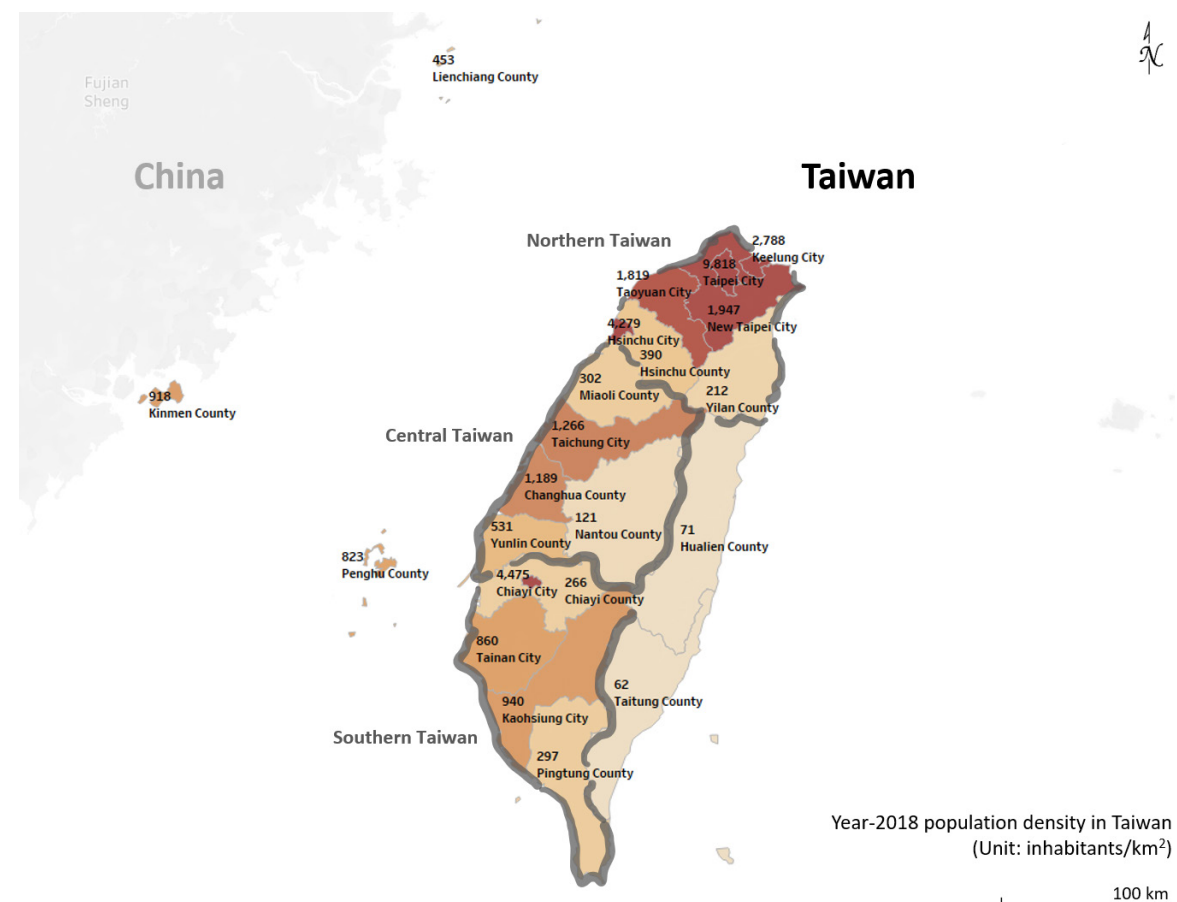

$\stackrel{4}{x}$

Figure 3. Population density in each county/city in Taiwan (Northern, Central, and Southern Taiwan as the study region)

The characteristic distributions of the valid respondents are shown in Table 2. Regarding individual demographics, gender was evenly distributed. Respondents aged above 65 years represented a high percentage $(31.08 \%)$, probably because the survey proceeded in the daytime and Taiwan has entered an aged society. Concerning travel characteristics, one-car (28.32\%) and two-scooter (34.59\%) households predominated in vehicle ownership. Since the scooter is the most prevalent travel tool of residents in Taiwan, $72.93 \%$ of the respondents held a scooter license. As to their daily travel habits, the main travel mode was the scooter which accounted for 39.35\% (as drivers/riders and passengers), and the second one was the car which represented $27.82 \%$, whereas public transit and walking only respectively represented $15.04 \%$ and $11.28 \%$. The above travel habit tendency was close to a large-scale official report indicating a $70.6 \%$ market share of private modes and an $18.2 \%$ one of public transit (MOTC, 2017). 
Table 2. Socio-economic and travel characteristics of respondents

\begin{tabular}{|c|c|c|c|}
\hline $\begin{array}{l}\text { Socio-economic } \\
\text { characteristics }\end{array}$ & $\begin{array}{l}\text { Percent of respondents } \\
(\mathrm{N}=399)\end{array}$ & Travel characteristics & $\begin{array}{l}\text { Percent of respondents } \\
(\mathrm{N}=399)\end{array}$ \\
\hline Gender & & Car ownership in household & \\
\hline Male & $50.88 \%$ & $0 \mathrm{car}$ & $15.79 \%$ \\
\hline Female & $49.12 \%$ & $1 \mathrm{car}$ & $49.12 \%$ \\
\hline Employment & & 2 cars & $28.07 \%$ \\
\hline Underemployment & $62.16 \%$ & 3 cars & $4.76 \%$ \\
\hline Without employment & $37.84 \%$ & 4 cars & $0.50 \%$ \\
\hline Age & & Above 5 cars & $1.75 \%$ \\
\hline Below 20 & $19.05 \%$ & Scooter ownership in household & \\
\hline $21-30$ years old & $7.02 \%$ & 0 scooter & $11.78 \%$ \\
\hline $31-40$ years old & $4.76 \%$ & 1 scooter & $28.32 \%$ \\
\hline $41-50$ years old & $9.02 \%$ & 2 scooters & $34.59 \%$ \\
\hline 51-54 years old & $17.29 \%$ & 3 scooters & $16.54 \%$ \\
\hline $55-59$ years old & $3.51 \%$ & 4 scooters & $5.51 \%$ \\
\hline 60-64 years old & $8.27 \%$ & Above 5 scooters & $3.26 \%$ \\
\hline 65-69 years old & $6.27 \%$ & Bicycle ownership in household & \\
\hline $70-74$ years old & $13.78 \%$ & 0 bicycle & $28.32 \%$ \\
\hline 75-79 years old & $7.27 \%$ & 1 bicycle & $32.83 \%$ \\
\hline More than 80 & $3.76 \%$ & 2 bicycles & $25.81 \%$ \\
\hline Monthly income or disposable & & 3 bicycles & $7.52 \%$ \\
\hline income $(\mathrm{NT} \$=0.033 \mathrm{US} \$)$ & & 4 bicycles & $3.51 \%$ \\
\hline Less than 10,000 & $11.53 \%$ & Above 5 bicycles & $2.01 \%$ \\
\hline $10,000-29,999$ & $33.83 \%$ & Car license & \\
\hline $30,000-59,999$ & $30.58 \%$ & Hold & $45.86 \%$ \\
\hline Above 60,000 & $11.28 \%$ & Not hold & $54.14 \%$ \\
\hline No income & $12.78 \%$ & Scooter license & \\
\hline Living region & & Hold & $72.93 \%$ \\
\hline Northern Taiwan & $15.28 \%$ & Not hold & $27.07 \%$ \\
\hline Central Taiwan & $54.38 \%$ & Ability to cycle & \\
\hline \multirow[t]{12}{*}{ Southern Taiwan } & $30.02 \%$ & Have & $66.42 \%$ \\
\hline & & Not have & $33.58 \%$ \\
\hline & & Main travel mode & \\
\hline & & Walk & $11.28 \%$ \\
\hline & & Public transit & $15.04 \%$ \\
\hline & & Car (driver) & $23.31 \%$ \\
\hline & & Car (passenger) & $4.51 \%$ \\
\hline & & Scooter (rider) & $38.10 \%$ \\
\hline & & Scooter (passenger) & $1.25 \%$ \\
\hline & & Taxi & $1.00 \%$ \\
\hline & & Bicycle & $4.01 \%$ \\
\hline & & Mobility e-scooter & $2.01 \%$ \\
\hline
\end{tabular}




\subsection{Variables and measurement}

\subsubsection{Adaptation of walkability factors}

The factors for investigating the PEW of residents were adapted from the NEWS according to Taiwan's social and built environment features. Taiwan has become an aged society with the population aged over 65 accounting for 14\% of the total population since 2018 (Chou, Wang, \& Lin, 2019). Moreover, massive two-wheel vehicles have often occupied pedestrian spaces, such as sidewalks and arcades (Hsieh, 2020). Hence, a negative factor of perceived physical obstruction was incorporated, as Cerin et al. (2010) considered such a factor for seniors in Hong Kong. The original eight NEWS factors in the literature (Cerin et al., 2006; Saelens, Sallis, Black, et al., 2003) were adopted, containing the perceptions of residential density, land-use mix diversity, land-use mix access, street connectivity, walking facilities, aesthetics, pedestrian/traffic safety, and crime safety (refer to Table 1). A total of nine factors that were adopted in the present study are shown in Table 3 .

\subsubsection{Design and refinement of walkability factor measures}

The measures of the added factor of physical obstruction were devised for the built environment in Taiwan. Therefore, physical obstruction measures involved the occupations of parked scooters and vendors on roadsides and sidewalks and in arcades. In addition, the items of general physical obstruction of walkability were also considered, including available paths (reversed item), upward or downward detours, the crowd, and convex obstacles (Cerin et al., 2010) (see "I. Physical obstruction" in Table 3).

Moreover, the abbreviated measures of NEWS (Cerin et al., 2006) were adapted and refined as follows:

(1) Given the high population density (650.41 inhabitants/km2) in Taiwan, "A. Residential density" (See Table 3) was extended to accommodate an added level of apartment or condominium stories (>20 stories), as Cerin et al. (2010) adapted the factor to Hong Kong.

(2) "B. Land-use mix diversity" (See Table 3) was assessed with short intervals of subjective walking time to daily services, considering that mixed land-use patterns in Taiwan have been more widespread than in western countries for which the original NEWS was developed.

(3) The daily service items in land-use mix diversity were adapted to Taiwan's typical daily services, such as adding "lottery store" and "religious place," and removing video and book store items in the NEWS. Also, the items were classified into six categories: food, clothing, affairs, mobility, education, and entertainment, to create a psychological factor, in contrast to a single average score of all items of land-use mix diversity in previous NEWS-related research. Substituting a psychological factor measured by the six categorical average scores for a single average score was because service items may not have equal contributions to the formation of perceived land-use mix diversity for residents. Hence, instead of an average score, this study adopted a composition structure for the factor of land-use mix diversity that could reflect different contributions (represented by different factor loadings) of service categories to the factor.

(4) Regarding the psychological scale of land-use mix diversity, previous research (Cerin et al., 2006; Saelens, Sallis, Black, et al., 2003) specified the response "don't know" (walking time) chosen by residents to be the lowest score as such a long distance that they did not know the required walking time. However, previous research ignored that not all service facilities could be a destination for residents. Hence, it makes an error to regard non-destination facilities as long-distance facilities. For measurement refinement, the present study incorporated the option "doesn't fit me," with which the facility item did not count in the average score of a category in land-use mix diversity, for a facility that a resident did not use in daily life. 
The measures of other factors are shown in Table 3, and their minor adaptations can be found by referring to the NEWS (Cerin et al., 2006).

Table 3. Perceived environment walkability factors and measures

\begin{tabular}{|c|c|c|c|}
\hline Factor & \multicolumn{2}{|l|}{ Measures } & Psychological scale \\
\hline A. Residential density & \multicolumn{2}{|c|}{$\begin{array}{l}\text { Consider the sphere of your daily activities surrounding your home... } \\
\text { A1. How common are detached single-family residences in your immediate } \\
\text { neighborhood? (weight: psychological scale*1) } \\
\text { A2. How common are townhouses or row houses of } 1-3 \text { stories in your im- } \\
\text { mediate neighborhood? (weight: psychological scale*10) } \\
\text { A3. How common are apartments or condos of } 4-6 \text { stories in your immediate } \\
\text { neighborhood? (weight: psychological scale*25) } \\
\text { A4. How common are apartments or condos of 7-12 stories in your immedi- } \\
\text { ate neighborhood? (weight: psychological scale*50) } \\
\text { A5. How common are apartments or condos of } 13-20 \text { stories in your imme- } \\
\text { diate neighborhood? (weight: psychological scale* } 85 \text { ) } \\
\text { A6. How common are apartments or condos of more than } 20 \text { stories in your } \\
\text { immediate neighborhood? (weight: psychological scale*130) }\end{array}$} & $\begin{array}{l}\text { none }=1, \text { a few }=2, \\
\text { some }=3, \text { many }=4, \\
\text { almost all }=5\end{array}$ \\
\hline $\begin{array}{l}\text { B. Land-use mix } \\
\text { diversity }\end{array}$ & $\begin{array}{l}\text { About how long would it take to } \\
\text { businesses or facilities listed belo } \\
\text { Food } \\
\text { B1. Restaurant/cafeteria/fast- } \\
\text { food store } \\
\text { B2. Coffee shop } \\
\text { B3. Traditional market } \\
\text { B4. Supermarket } \\
\text { Clothing } \\
\text { B5. Clothing store } \\
\text { B6. Laundry cleaner } \\
\text { B7. Salon/barbershop } \\
\text { Affairs } \\
\text { B8. Convenience store/small } \\
\text { grocery store } \\
\text { B9. Hardware store/big grocery } \\
\text { store } \\
\text { B10. Clinic } \\
\text { B11. Hospital } \\
\text { B12. Pharmacy/drug store } \\
\text { B13. Religious place (temple, } \\
\text { monastery, church, or chapel) } \\
\text { B14. Bank/post office } \\
\text { B15. Kindergarten/nursery/ } \\
\text { elementary school (pick up } \\
\text { children) } \\
\text { B16. Dumping the garbage }\end{array}$ & $\begin{array}{l}\text { get from your origin place to the nearest } \\
\text { if you walked to them? } \\
\text { Mobility } \\
\text { B17. Metro station } \\
\text { B18. Bus stop } \\
\text { B19. Public toilet } \\
\text { Education } \\
\text { B20. Library/bookstore } \\
\text { B21. Cultural center/exhibition center/gal- } \\
\text { lery/museum } \\
\text { Entertainment } \\
\text { B22. Community activity center/elderly } \\
\text { activity center } \\
\text { B23. Park/campus/sports facility or place } \\
\text { B24. Recreation place (department store, } \\
\text { cinema, or karaoke) } \\
\text { B25. Lottery store } \\
\text { B26. House of family or relatives } \\
\text { B27. House of close friends }\end{array}$ & $\begin{array}{l}1-2 \min =5,3-5 \min =4, \\
6-10 \min =3,11-20 \min =2, \\
\text { over } 20 \min =1 \text {, don't know }=1 \text {, } \\
\text { doesn't fit me = removing the } \\
\text { item from average score calcula- } \\
\text { tion instead of substituting } 1 \\
\text { or } 0\end{array}$ \\
\hline $\begin{array}{l}\text { C. Land-use mix } \\
\text { access }\end{array}$ & $\begin{array}{l}\text { Consider the sphere of your dail } \\
\text { C1. You can walk to the places v } \\
\text { errands from your home. } \\
\text { C2. You can go to many places } \\
\text { C3. It is easy to walk to a metro } \\
\text { C4. It is convenient to take the }\end{array}$ & $\begin{array}{l}\text { activities surrounding your home... } \\
\text { here you often go for shopping or running } \\
\text { om your home on foot. } \\
\text { tation or a bus stop from your home. } \\
\text { etro or bus for shopping or running errands. }\end{array}$ & $\begin{array}{l}\text { strongly disagree }=1, \\
\text { somewhat disagree }=2, \\
\text { neutral }=3, \\
\text { somewhat agree }=4, \\
\text { strongly agree }=5\end{array}$ \\
\hline
\end{tabular}




\begin{tabular}{|c|c|c|}
\hline Factor & Measures & Psychological scale \\
\hline D. Street connectivity & $\begin{array}{l}\text { Consider the sphere of your daily activities surrounding your home... } \\
\text { D1. Walking from an intersection to another does not take much time. } \\
\text { D2. There are many alternative routes for walking to a shop or run errands. }\end{array}$ & $\begin{array}{l}\text { strongly disagree }=1, \\
\text { somewhat disagree }=2, \\
\text { neutral }=3, \text { somewhat agree }=4, \\
\text { strongly agree }=5\end{array}$ \\
\hline E. Walking facilities & $\begin{array}{l}\text { Consider the sphere of your daily activities surrounding your home... } \\
\text { E1. There are sidewalks on most of the streets. } \\
\text { E2. The sidewalks are broad. } \\
\text { E3. The sidewalks in my neighborhood are maintained level. } \\
\text { E4. The streets are well lit at night. } \\
\text { E5. There are crosswalks and pedestrian signals to help walkers cross busy } \\
\text { streets. } \\
\text { E6. There are many trees between the sidewalks and the traffic lanes. } \\
\text { E7. There are seats or places for a rest on the streets. }\end{array}$ & $\begin{array}{l}\text { strongly disagree }=1, \\
\text { somewhat disagree }=2, \\
\text { neutral }=3, \text { somewhat agree }=4, \\
\text { strongly agree }=5\end{array}$ \\
\hline F. Aesthetics & $\begin{array}{l}\text { Consider the sphere of your daily activities surrounding your home... } \\
\text { F1. There are many trees along the streets. } \\
\text { F2. There are interesting things to look at on the streets. } \\
\text { F3. There are many attractive natural sights. } \\
\text { F4. There are many attractive buildings. } \\
\text { F5. The streets are tidy. }\end{array}$ & $\begin{array}{l}\text { strongly disagree }=1, \\
\text { somewhat disagree }=2, \\
\text { neutral }=3, \text { somewhat agree }=4, \\
\text { strongly agree }=5\end{array}$ \\
\hline $\begin{array}{l}\text { G. Pedestrian/traffic } \\
\text { safety }\end{array}$ & $\begin{array}{l}\text { Consider the sphere of your daily activities surrounding your home... } \\
\text { G1. There is so much traffic on the streets.* } \\
\text { G2. The speed of traffic on the streets is usually fast.* } \\
\text { G3. The parked vehicles beside the streets usually obstruct my view.* } \\
\text { G4. The vehicles in parking or departure beside the streets usually conflict } \\
\text { with pedestrians.* } \\
\text { G5. The vehicles passing the entrances and exits of parking lots usually con- } \\
\text { flict with pedestrians.* } \\
\text { G6. The bicycles in riding on the streets usually conflict with pedestrians.* } \\
\text { G7. It is usual to inhale exhaust fumes on the streets.* } \\
\text { G8. The streets or the sidewalks are very slippery on rainy days or after rain.* }\end{array}$ & $\begin{array}{l}* \text { reverse-scored item; } \\
\text { strongly disagree }=1, \\
\text { somewhat disagree }=2, \\
\text { neutral }=3, \text { somewhat agree }=4, \\
\text { strongly agree }=5\end{array}$ \\
\hline H. Crime safety & $\begin{array}{l}\text { Consider the sphere of your daily activities surrounding your home... } \\
\text { H1. Crime safety should be improved.* } \\
\text { H2. I feel unsafe when walking on the streets at night.* }\end{array}$ & $\begin{array}{l}* \text { reversed-score item; } \\
\text { strongly disagree }=1, \\
\text { somewhat disagree }=2, \\
\text { neutral }=3, \text { somewhat agree }=4 \text {, } \\
\text { strongly agree }=5\end{array}$ \\
\hline I. Physical obstruction & $\begin{array}{l}\text { Consider the sphere of your daily activities surrounding your home... } \\
\text { I1. There are many arcades beside the streets to walk.* } \\
\text { I2. The streets or arcades are usually occupied by stores or vendors. } \\
\text { I3. The streets or arcades are usually occupied by parked vehicles. } \\
\text { I4. It is usually needed to use skywalks or underground walkways when walk- } \\
\text { ing to the places where you want to go. } \\
\text { I5. There are too many pedestrians on the streets for you to walk well. } \\
\text { I6. Many obstacles convex or obstructed on the way make it difficult to walk. }\end{array}$ & $\begin{array}{l}* \text { reversed-score item; } \\
\text { strongly disagree }=1, \\
\text { somewhat disagree }=2, \\
\text { neutral }=3, \text { somewhat agree }=4 \text {, } \\
\text { strongly agree }=5\end{array}$ \\
\hline
\end{tabular}

\subsubsection{Walking behavior}

(1) Purposive walking

For walking behavior assessment, this study referred to the question format of physical activity in the International Physical Activity Questionnaire (IPAQ) (Craig et al., 2003) to investigate walking frequency and duration during the last seven days. Specifically, respondents reported how many days they "walked to a specific destination generating before departure (premeditated destination)," defined as "purposive walking" (similar to from-place-to-place walking in the IPAQ). Then, they reported how much time per day they walked, as mentioned above on average. Therefore, total purposive walking frequency (days) 
and duration (minutes) per week were obtained in an easier way to self-report for respondents.

(2) Discursive walking

Respondents were asked to report how many days they "walked without a destination before departure" during the last seven days. Such a walk was defined as "discursive walking" based on the concept of strolling, roaming, or other purposes satisfied during walking (Wunderlich, 2008). Distinguished from premeditated destinations in purposive walking, the generation of a destination visited but not decided before departure by respondents during a walk (spontaneous destination) did not change the walk as discursive walking. Afterward, they reported how much time per day they walked as defined above on average. Total discursive walking frequency (days) and duration (minutes) were calculated. Fig. 4 provides an example illustrating the difference between purposive and discursive walking according to their definitions mentioned above. Since the survey was conducted through face-to-face interviews, the interviewers could provide instructions when respondents reported walking behavior.

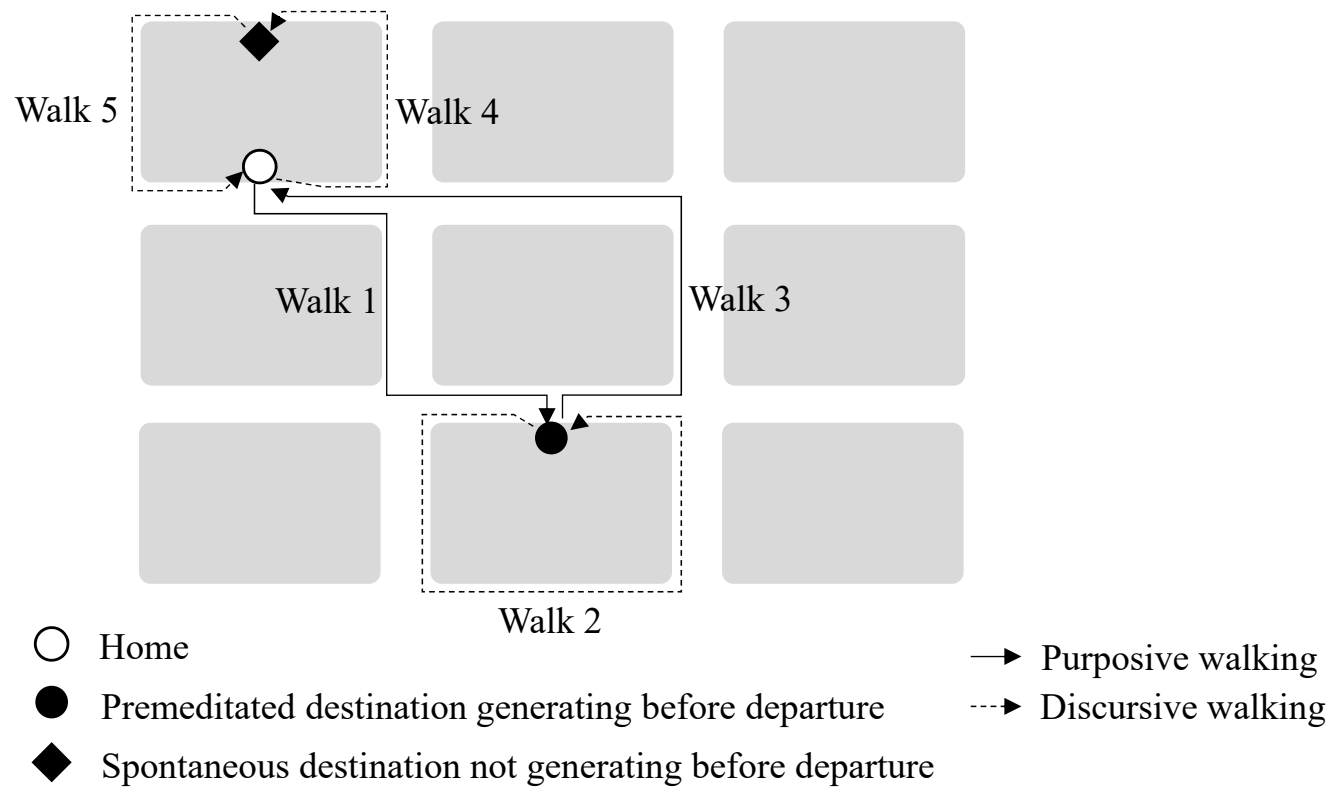

Figure 4. Taxonomy for purposive and discursive walking

\subsection{Constructing walkability factors}

The internal consistency among measures within a factor was examined by Cronbach's alpha except for residential density, whose different housing density items were weighted by density levels (Cerin et al., 2006) to obtain a single score. The reliability of all factors according to the specifications in Table 3 was satisfactory or above ( $\geqq 0.6$ ) (Taber, 2018) (see Table 4). The validity of factors was assessed by confirmatory factor analysis with the criterion of factor loadings above 0.5 (Shevlin, Miles, Davies, \& Walker, 2000), and all factor loadings met the criterion except for G1, G2, and H1 (see Table 5). In pedestrian/ traffic safety, the respondents may not perceive traffic volume (G1) and traffic speed (G2) as the same factor as measured by other components. This situation implied that pedestrians in Taiwan were con- 
cerned with the safety of walking paths instead of traffic roads. Thus, the two measures were excluded from pedestrian/traffic safety, and then the factor loadings meeting the criterion were obtained in the adjusted factor. Moreover, the measure regarding the lack of building arcades for walking (as a reversescored item; I1) in the factor of physical obstruction was removed because of exhibiting a negative factor loading and thus reflecting an opposite factor. This result was probably because arcades were often occupied by vendors and parked vehicles in Taiwan so that no matter how many arcades are provided in a neighborhood, the perceived degree of physical obstruction would not be markedly changed. Therefore, the presence of arcades was probably linked with much physical obstruction by respondents. The reliability and factor loading results of the revised factors are respectively included in Table 4 and Table 5.

Table 4. Reliability of walkability factors

\begin{tabular}{|c|c|c|c|c|c|}
\hline Factor & Cronbach's alpha & Reliability & Factor & Cronbach's alpha & Reliability \\
\hline $\begin{array}{l}\text { A. Residential } \\
\text { density }\end{array}$ & - & - & $\begin{array}{l}\text { G. Pedestrian/ } \\
\text { traffic safety }\end{array}$ & 0.85 & Satisfactory \\
\hline $\begin{array}{l}\text { B. Land-use mix } \\
\text { diversity }\end{array}$ & 0.88 & Satisfactory & $\begin{array}{l}\mathrm{G}^{\prime} . \text { Pedestrian/ } \\
\text { traffic safety } \\
\text { (removing G1 \& } \\
\text { G2) }\end{array}$ & 0.86 & Satisfactory \\
\hline $\begin{array}{l}\text { C. Land-use mix } \\
\text { access }\end{array}$ & 0.85 & Satisfactory & H. Crime safety & 0.74 & Satisfactory \\
\hline $\begin{array}{l}\text { D. Street con- } \\
\text { nectivity }\end{array}$ & 0.78 & Satisfactory & $\begin{array}{l}\mathrm{H}^{\prime} \text {. Crime safety } \\
\text { (removing } \mathrm{H} 1 \text { ) }\end{array}$ & - & - \\
\hline $\begin{array}{l}\text { E. Walking facili- } \\
\text { ties }\end{array}$ & 0.87 & Satisfactory & $\begin{array}{l}\text { I. Physical } \\
\text { obstruction }\end{array}$ & 0.65 & Acceptable \\
\hline F. Aesthetics & 0.82 & Satisfactory & $\begin{array}{l}\text { I'. Physical } \\
\text { obstruction } \\
\text { (removing I1) }\end{array}$ & 0.87 & Satisfactory \\
\hline
\end{tabular}

Note: The prime signs of $\mathrm{G}^{\prime}, \mathrm{H}^{\prime}$, and $\mathrm{I}^{\prime}$ are used to represent the factors after removing any measures. This representation is also applicable to Table 5 and Table 6. 
Table 5. Confirmatory factor analysis of walkability factors

\begin{tabular}{|c|c|c|c|c|c|}
\hline $\begin{array}{l}\text { Factor } \\
\text { (Mean and SD) }\end{array}$ & Measures & Factor loadings & $\begin{array}{l}\text { Factor } \\
\text { (Mean and SD) }\end{array}$ & Measures & $\begin{array}{l}\text { Factor } \\
\text { loadings }\end{array}$ \\
\hline $\begin{array}{l}\text { A. Residential density } \\
(\text { mean }=593, S D=249.56)\end{array}$ & - & - & $\begin{array}{l}\text { G. Pedestrian/traffic safety } \\
(\text { mean }=3.02, S D=0.74)\end{array}$ & $\begin{array}{l}\text { G1 } \\
\text { G2 } \\
\text { G3 } \\
\text { G4 } \\
\text { G5 } \\
\text { G6 } \\
\text { G7 } \\
\text { G8 }\end{array}$ & $\begin{array}{l}0.33^{* *} \\
0.48^{* *} \\
0.68^{* *} \\
0.81^{* *} \\
0.80^{* *} \\
0.73^{* *} \\
0.62^{* *} \\
0.64^{* *}\end{array}$ \\
\hline $\begin{array}{l}\text { B. Land-use mix diversity } \\
(m e a n=2.40, S D=0.91)\end{array}$ & $\begin{array}{l}\text { B1 } \\
\text { B2 } \\
\text { B3 } \\
\text { B4 } \\
\text { B5 } \\
\text { B6 }\end{array}$ & $\begin{array}{l}0.81^{* *} \\
0.76^{* *} \\
0.82^{* *} \\
0.69^{* *} \\
0.72^{* *} \\
0.72^{* *}\end{array}$ & $\begin{array}{l}\mathrm{G}^{\prime} . \text { Pedestrian/traffic safety } \\
\text { (removing G1 \& G2) } \\
(\text { mean=3.13, SD=0.84) }\end{array}$ & $\begin{array}{l}\text { G3 } \\
\text { G4 } \\
\text { G5 } \\
\text { G6 } \\
\text { G7 } \\
\text { G8 }\end{array}$ & $\begin{array}{l}0.66^{* *} \\
0.83^{* *} \\
0.84^{* *} \\
0.77^{* *} \\
0.57^{* *} \\
0.62^{* *}\end{array}$ \\
\hline $\begin{array}{l}\text { C. Land-use mix access } \\
(\text { mean }=3.22, S D=1.06)\end{array}$ & $\begin{array}{l}\mathrm{C} 1 \\
\mathrm{C} 2 \\
\mathrm{C} 3 \\
\mathrm{C} 4 \\
\end{array}$ & $\begin{array}{l}0.77^{* *} \\
0.83^{* *} \\
0.74^{* *} \\
0.75^{* *}\end{array}$ & $\begin{array}{l}\text { H. Crime safety } \\
(\text { mean }=3.35, \mathrm{SD}=0.96)\end{array}$ & $\begin{array}{l}\mathrm{H} 1 \\
\mathrm{H} 2\end{array}$ & $\begin{array}{l}0.77^{* *} \\
0.77^{* *}\end{array}$ \\
\hline $\begin{array}{l}\text { D. Street connectivity } \\
(\text { mean }=3.59, S D=0.95)\end{array}$ & $\begin{array}{l}\mathrm{D} 1 \\
\mathrm{D} 2\end{array}$ & $\begin{array}{l}0.80^{* *} \\
0.80^{* *}\end{array}$ & $\begin{array}{l}\mathrm{H}^{\prime} . \text { Crime safety } \\
(\text { removing } \mathrm{H} 1) \\
(\text { mean }=3.39, \mathrm{SD}=1.08)\end{array}$ & $\mathrm{H} 2$ & 1.00 \\
\hline $\begin{array}{l}\text { E. Walking facilities } \\
(\text { mean }=3.01, S D=0.80)\end{array}$ & $\begin{array}{l}\text { E1 } \\
\text { E2 } \\
\text { E3 } \\
\text { E4 } \\
\text { E5 } \\
\text { E6 } \\
\text { E7 }\end{array}$ & $\begin{array}{l}0.79^{* *} \\
0.84^{* *} \\
0.82^{* *} \\
0.50^{* *} \\
0.62^{* *} \\
0.61^{* *} \\
0.66^{* *}\end{array}$ & $\begin{array}{l}\text { I. Physical obstruction } \\
(\text { mean }=2.69, S D=0.71)\end{array}$ & $\begin{array}{l}\text { I1 } \\
\text { I2 } \\
\text { I3 } \\
\text { I4 } \\
\text { I5 } \\
\text { I6 }\end{array}$ & $\begin{array}{l}-0.56^{* *} \\
0.81^{* *} \\
0.73^{* *} \\
0.70^{* *} \\
0.82^{* *} \\
0.75^{* *}\end{array}$ \\
\hline $\begin{array}{l}\text { F. Aesthetics } \\
(\text { mean }=2.99, \mathrm{SD}=0.81)\end{array}$ & $\begin{array}{l}\text { F1 } \\
\text { F2 } \\
\text { F3 } \\
\text { F4 } \\
\text { F5 }\end{array}$ & $\begin{array}{l}0.65^{* *} \\
0.73^{* *} \\
0.78^{* *} \\
0.72^{* *} \\
0.53^{* *}\end{array}$ & $\begin{array}{l}\mathrm{I}^{\prime} . \text { Physical obstruction } \\
\text { (removing I1) } \\
(\text { mean }=2.58, \mathrm{SD}=0.95)\end{array}$ & $\begin{array}{l}\text { I2 } \\
\text { I3 } \\
\text { I4 } \\
\text { I5 } \\
\text { I6 }\end{array}$ & $\begin{array}{l}0.81^{\text {** }} \\
0.72^{\text {** }} \\
0.68^{\text {** }} \\
0.83^{\text {** }} \\
0.76^{\text {** }}\end{array}$ \\
\hline
\end{tabular}

Note: ${ }^{* *} p<0.05$. Refer to Table 3 for measures. Standardized factor loadings are presented.

\section{$4 \quad$ Association between perceived environment walkability and walking behavior}

Based on the above-developed factors of PEW, this study used structural equation modeling to examine the associations between PEW factors and walking behavior. For comparison between the determinants of purposive and discursive walking, modeling was first separated by two measures of walking (frequency and duration) and then by two types of walking (purposive walking and discursive walking) and total walking (summation of a measure of both types of walking). Offending estimates (negative error variance estimates, standardized coefficients exceeding 1.0 or above 0.95 , or overlarge standard errors) should be first inspected for model modification (Anderson \& Gerbing, 1988). The standardized coefficient of $\mathrm{H} 1$ in physical obstruction exceeded 1 in modeling, and thus $\mathrm{H} 1$ was excluded (Table 4 and Table 5 reflecting this exclusion). This estimate may be because the description of this item, originating 
from the item of crime rate in the NEWS (Cerin et al., 2006), was so general that it approximated the overall level of its factor. Also, in the modeling of purposive walking frequency, since the negative error variance of D2 in street connectivity represented an offending estimate, it was speculated that the measurement errors in street connectivity measures and those in land-use mix access were intercorrelated. Thus, a correlation relationship between street connectivity and land-use mix access was added to produce a positive error variance of D2. After addressing the offending situations, the estimation results of models are shown in Table 6.

Table 6. Estimation results of perceived environment walkability impacts on walking behavior

\begin{tabular}{|lllllll|}
\hline Factor & \multicolumn{2}{l}{$\begin{array}{l}\text { Walking frequency model coefficient } \\
\text { (standardized coefficient) }\end{array}$} & \multicolumn{2}{l}{$\begin{array}{l}\text { Walking duration model coefficient } \\
\text { (standardized coefficient) }\end{array}$} \\
\cline { 2 - 7 } & Total & $\begin{array}{l}\text { Purposive } \\
\text { walking }\end{array}$ & $\begin{array}{l}\text { Discursive } \\
\text { walking }\end{array}$ & $\begin{array}{l}\text { Total } \\
\text { Purposive walk- }\end{array}$ & $\begin{array}{l}\text { Discursive } \\
\text { walking }\end{array}$ \\
\hline A. Residential density & $0.00(0.11)^{* *}$ & $0.00(0.16)^{* *}$ & $0.00(0.03)$ & $0.85(0.11)^{* *}$ & $0.07(0.14)^{* *}$ & $11.46(0.04)$ \\
B. Land-use mix diversity & $-0.44(-0.09)^{*}$ & $-0.27(-0.09)^{*}$ & $-0.13(-0.07)$ & $-2.53(-0.01)$ & $-7.02(-0.04)$ & $3.34(0.04)$ \\
C. Land-use mix access & $0.58(0.16)^{*}$ & $0.40(0.18)^{* *}$ & $0.18(0.10)^{* *}$ & $23.37(0.11)^{* *}$ & $11.70(0.08)$ & $10.88(0.12)^{* *}$ \\
D. Street connectivity & $0.29(0.09)$ & $0.12(0.06)$ & $0.25(0.10)^{* *}$ & $30.71(0.14)^{* *}$ & $19.69(0.14)^{* *}$ & $9.72(0.10)$ \\
E. Walking facilities & $0.09(0.02)$ & $0.23(0.08)$ & $-0.11(-0.06)$ & $-4.51(-0.02)$ & $6.74(0.04)$ & $-8.86(-0.09)^{*}$ \\
F. Aesthetics & $0.46(0.10)^{*}$ & $0.03(0.01)$ & $0.43(0.18)^{* *}$ & $14.50(0.06)$ & $3.07(0.02)$ & $11.46(0.10)^{*}$ \\
G'. Pedestrian/traffic safety & $-0.19(-0.04)$ & $-0.28(-0.09)^{*}$ & $0.09(0.03)$ & $16.00(-0.05)$ & $-21.68(-0.11)^{* *}$ & $5.74(0.04)$ \\
H'. Crime safety & $0.23(0.08)$ & $0.07(0.04)$ & $0.16(0.10)^{* *}$ & $4.62(0.03)$ & $-0.18(0.00)$ & $4.74(0.06)$ \\
I'. Physical obstruction & $0.13(0.04)$ & $-0.10(-0.05)$ & $0.22(0.13)^{* *}$ & $-1.16(-0.01)$ & $-7.84(-0.06)$ & $6.72(0.07)$ \\
\hline Sample size & 399 & 399 & 399 & 399 & 399 & 399 \\
CMIN/DF & 4.665 & 4.651 & 5.018 & 5.008 & 4.996 & 5.023 \\
RMSEA & 0.096 & 0.096 & 0.100 & 0.100 & 0.100 & 0.101 \\
GFI & 0.681 & 0.681 & 0.656 & 0.657 & 0.657 & 0.656 \\
CFI & 0.715 & 0.716 & 0.687 & 0.688 & 0.688 & 0.687 \\
\hline
\end{tabular}

Note: ${ }^{* *} p<0.05 ;{ }^{*} p<0.1$. Refer to Table 3 for the measures of the factors. Standardized coefficients (ranging from -1 to 1 ) are displayed for standardized effects, eliminating the influence of measurement units.

\subsection{Association of perceived environment walkability with walking frequency}

For total walking frequency, respondents tended to walk more frequently when they perceived higher residential density, land-use mix access, and aesthetics in their daily activity areas, but less frequently when perceiving higher land-use mix diversity (see Table 6). The former result showed the factors promoting the willingness to walk. The latter result corresponds to the literature reporting that diverse land use may lead to fewer total trips (Mahadevia \& Advani, 2016) and less walking (Manoj \& Verma, 2016). Noteworthily, diverse land use may decrease walking frequency given the same level of walking duration (Table 6 shows no significant influence of land-use mix diversity on total walking duration). The results implied that the possibility of satisfying multiple purposes on the way of a walk may promote the convenience of walking (decrease in frequency but not in duration).

With considering walking types, purposive walking frequency was positively associated with residential density and land-use mix access (particularly to shopping or running errands (C1) and many places (C2) with factor loading (FL) above 0.8; see Fig. 5). In contrast, purposive walking frequency was negatively associated with land-use mix diversity (especially for food (B1) and affairs (B3) with FL 
above 0.8). A negative association between purposive walking frequency and pedestrian/traffic safety was found. It could be speculated that there were both more severe traffic conflicts and higher travel demand in a prosperous district, where respondents perceived lower pedestrian/traffic safety but generated more trips than those in an unprosperous district.

The correlates of the frequency of discursive walking largely differed from those of purposive walking. Land-use mix access was found to be the only common influencing factor of both types of walking frequency. This factor had a higher impact on purposive walking frequency (standardized coefficient $=0.18$ ) than on discursive walking frequency (standardized coefficient $=0.10$ ) because accessibility may create marked transport efficiency. Thus, land-use mix access may trigger purposive walking, such as commuting or shopping walks, and discursive walking despite having not decided a destination before generating it. Respondents tended to walk discursively more frequently when they perceived higher land-use mix access (particularly to shopping or running errands (C1) and many places (C2) with FL above 0.8) (see Fig. 6), street connectivity (especially for alternative routes (D2) with LF above 0.8), aesthetics (especially for interesting things (F2), attractive natural sights (F3), and attractive buildings (F4) with LF above 0.7), and crime safety in their daily activity areas. In addition, although ignored by purposive pedestrians, street connectivity encouraging walking at random, aesthetics creating attractiveness during walking, and crime safety providing a relaxing environment may facilitate discursive walking generation. Moreover, physical obstruction was, however, positively correlated with discursive walking frequency. This association was probably because discursive walking demand may be more likely to emerge in a prosperous environment, where more interference from other road users such as vendors and parked vehicles was perceived.

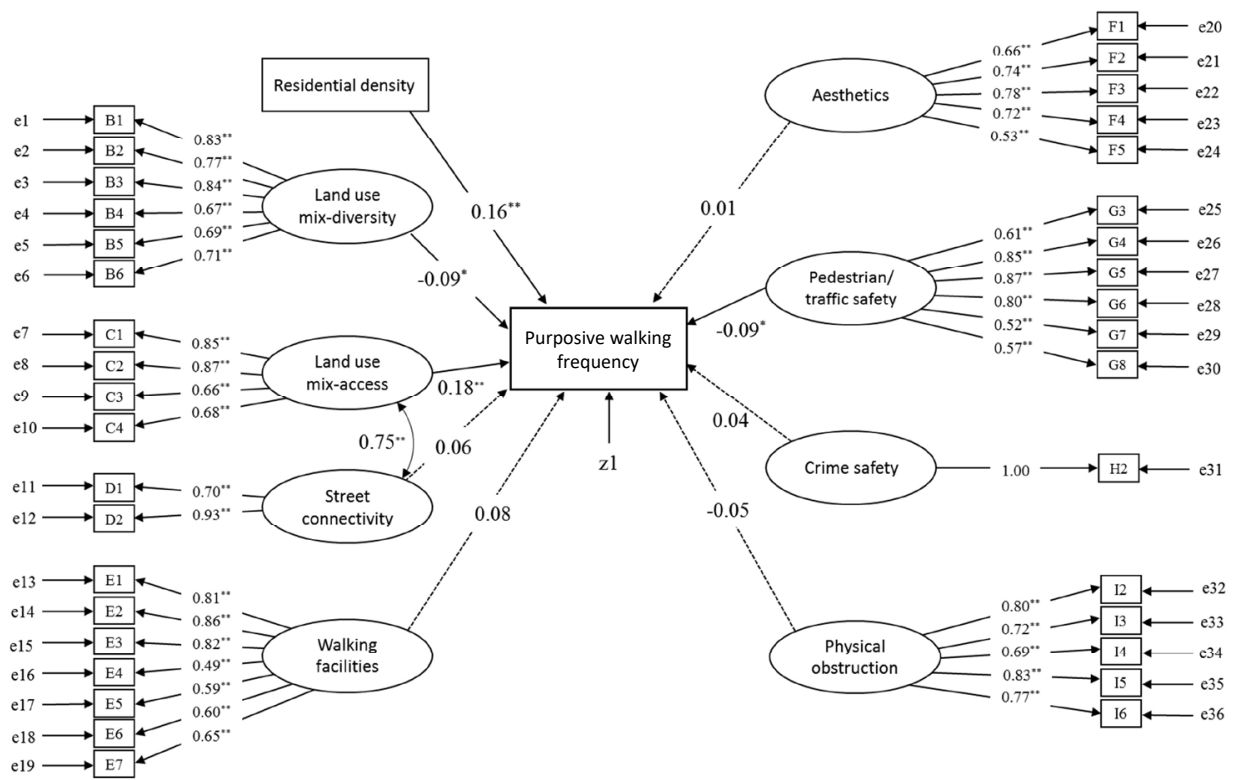

Figure 5. Structural and measurement model of purposive walking frequency

(See Table 3 for the measures. ${ }^{* *} p<0.05,{ }^{*} p<0.1$. The values are standardized coefficients. The term " $\mathrm{e}$ " denotes an error term of a dependent variable in a measurement model, and " $\mathrm{z}$ " denotes the error term of the dependent variable in the structural model.) 


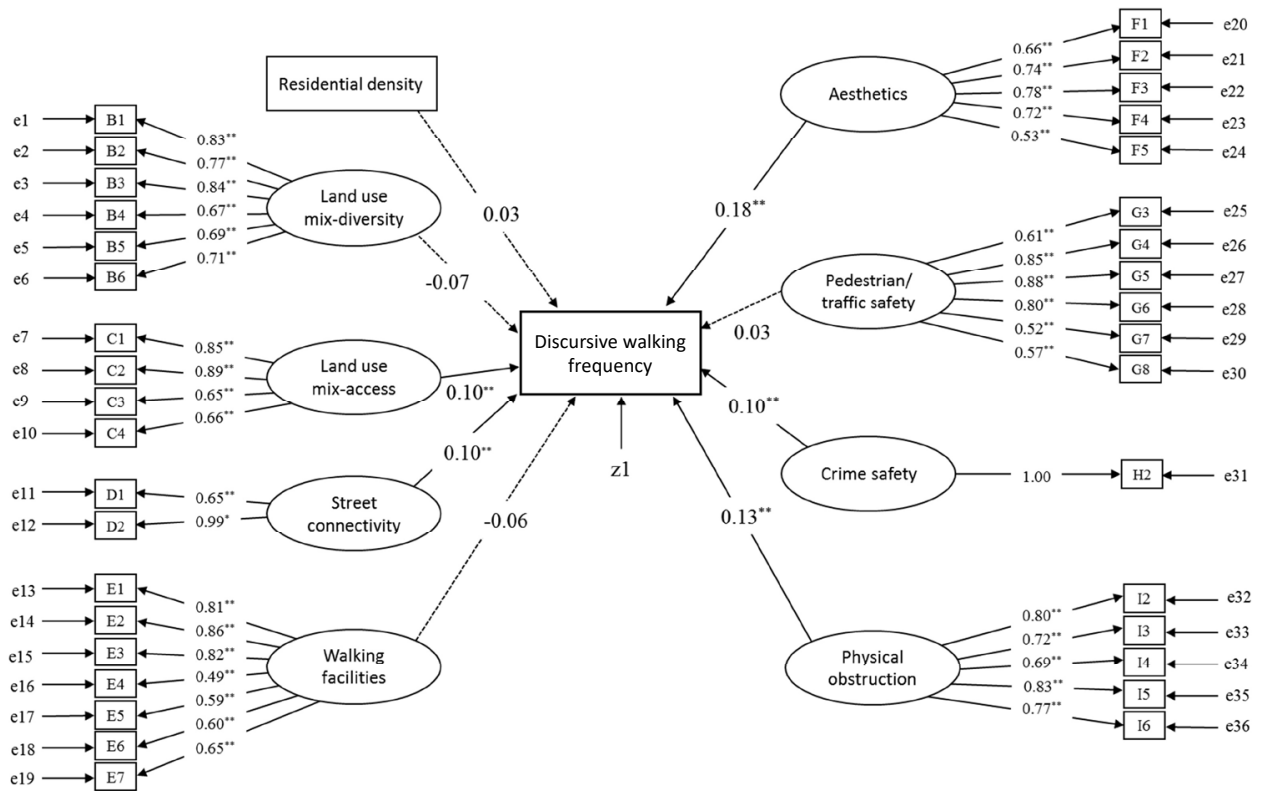

Figure 6. Structural and measurement model of discursive walking frequency

(See Table 3 for the measures. ${ }^{* *} p<0.05,{ }^{*} p<0.1$. The values are standardized coefficients. The term " $\mathrm{e}$ " denotes an error term of a dependent variable in a measurement model, and " $\mathrm{z}$ " denotes the error term of the dependent variable in the structural model.)

\subsection{Association of perceived environment walkability with walking duration}

The total walking duration model suggested that respondents were more likely to walk for a longer time when they perceived higher residential density, land-use mix access, and street connectivity in the environment (see Table 6). Therein, residential density and land-use mix access were common positive correlates of walking frequency and duration.

With considering walking types, purposive walking duration was positively associated with residential density and street connectivity. However, its association with land-use mix access was not found, probably because the effect of accessibility creating shorter walking time (Manoj \& Verma, 2016) may offset the effect of accessibility facilitating walking trip generation (refer to the significant positive coefficient of land-use mix access in the purposive walking frequency model in Table 6). Purposive walking included various types of walk trips with designated destinations. Hence, purposive walkers could arrange more walking destinations when they perceived high street connectivity, which may increase their willingness to walk purposively to generate longer purposive walking duration. By contrast, street connectivity was not significantly associated with purposive walking frequency, probably because working purpose may be dominant so that street connectivity seems not enough to increase purposive walking days per week. Thus, the promotion in purposive walking frequency may depend on land-use mix access (see the coefficient of land-use mix access for purposive walking frequency in Table 6). Moreover, high pedestrian/traffic safety was associated with shorter purposive walking duration. This association implied that the fewer conflicts, especially with vehicles in parking (G4) and driving (G5) and bicycles in riding (G6) with LF above 0.8 (see Fig. 7), the respondents confronted, the less time they consumed in purposive walking, such as shorter time of walking to work/school or shop in a higher pedestrian/ traffic safety environment.

Differently from purposive walking, respondents were inclined to walk discursively for a longer time when they perceived higher land-use mix access (particularly to shopping or running errands $(\mathrm{C} 1)$ 
and many places (C2) with LF above 0.8) and aesthetics (particularly for interesting things (F2), attractive natural sights (F3), and attractive buildings (F4) with FL above 0.7; see Fig. 8). This result suggested that long-time discursive walking could be triggered by the accessibility of potential destinations that had not been generated before departure, in addition to attractive streetscapes. Interestingly, however, the level of walking facilities was negatively correlated with discursive walking duration. This observation may be partly because the sidewalks broader or well maintained may pull more hurried pedestrians for commuting (Inoue et al., 2010), which may interfere with long-time discursive walking.

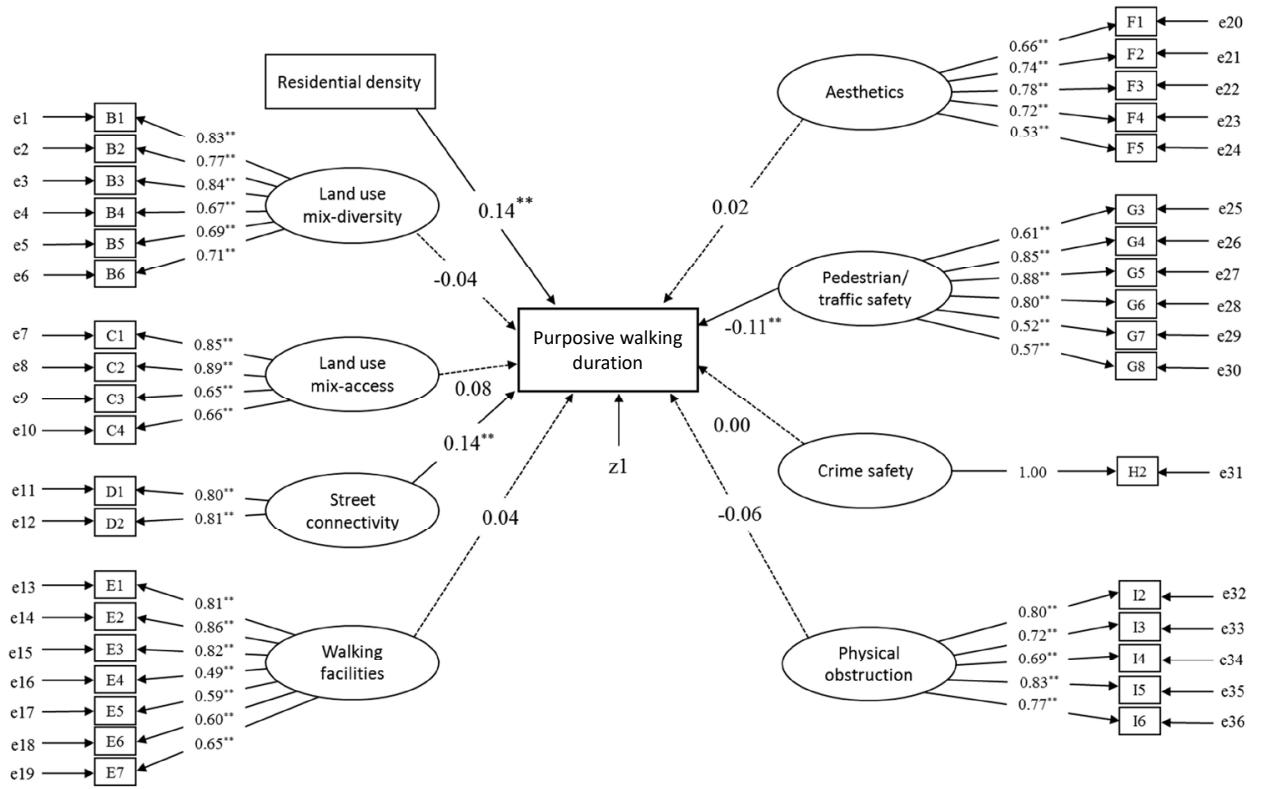

Figure 7. Structural and measurement model of purposive walking duration

(See Table 3 for the measures. ${ }^{* *} p<0.05,{ }^{*} p<0.1$. The values are standardized coefficients. The term " $\mathrm{e}$ " denotes an error term of a dependent variable in a measurement model, and " $\mathrm{z}$ " denotes the error term of the dependent variable in the structural model.)

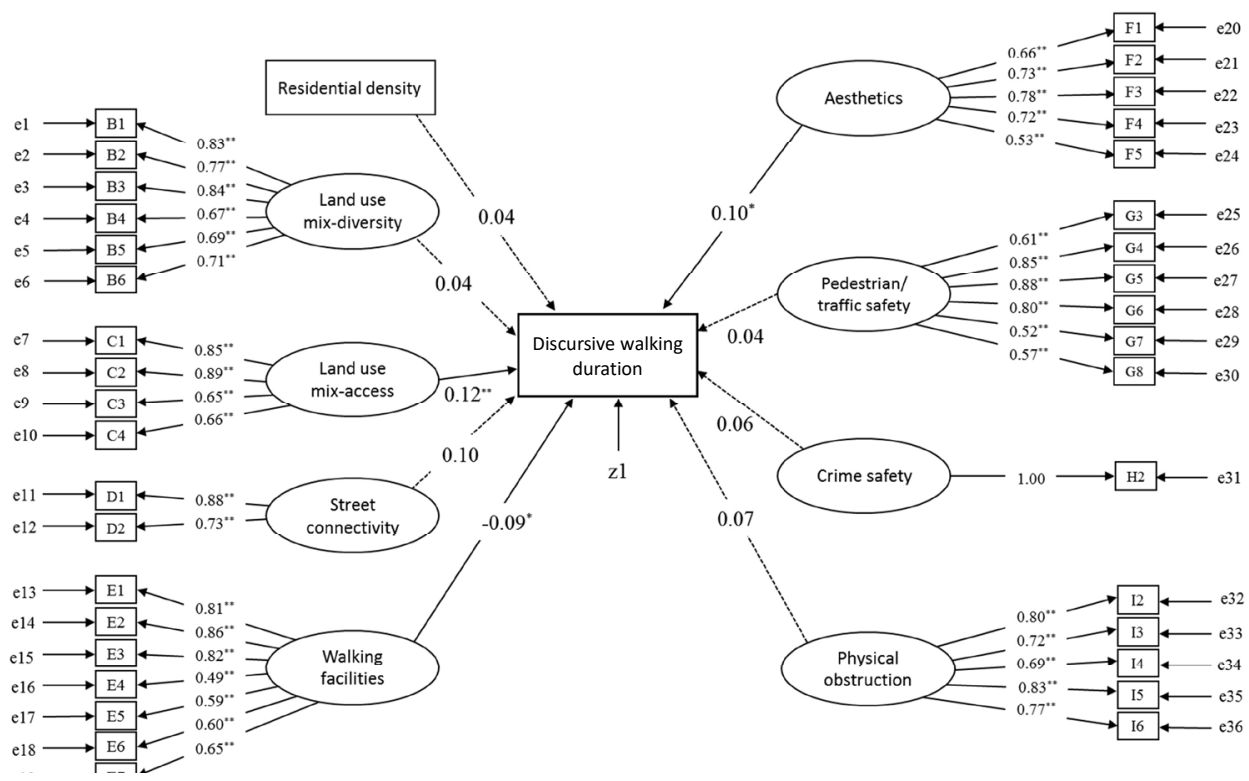

Figure 8. Structural and measurement model of discursive walking duration

(See Table 3 for the measures. ${ }^{* *} p<0.05,{ }^{*} p<0.1$. The values are standardized coefficients. The term "e" denotes an error term of a dependent variable in a measurement model, and " $\mathrm{z}$ " denotes the error term of the dependent variable in the structural model.) 


\section{$5 \quad$ Urban design based on association between perceived environment walkability and walking behavior}

Urban planners or designers should understand the impact on walking when applying any urban design tools shaping the built environment. The aforementioned findings regarding the environmental determinants of purposive and discursive walking could provide the basis for formulating walkable urban design strategies. The three sequential hierarchies of urban design tools in Taiwan, containing land-use plans and land-use zoning control for publicly and privately owned lands and urban design guidelines for privately owned lands and buildings, could be applied to change physical features, improve environment walkability, and in turn facilitate walking behavior (Ewing \& Handy, 2009). Therefore, the present section discusses how to shape a walkable environment by using urban design tools based on the identified associations between environment walkability (captured by PEW) and walking behavior. The PEW-walking associations, their mechanisms inferred, and corresponding urban design strategies for environment walkability improvement are organized in Table 7.

- Increase in residential density: High residential density with enough population underpins the possibility of the concentration of service facilities, which is a necessary condition of street vitality (Jacobs, 1961). Although high residential density (e.g., a high-density district with pure residence) cannot directly create walkability, it provides environmental competence in supporting land use with various service facilities within acceptable walking distance and high accessibility to working, shopping, or leisure. Thus, more frequent and longer purposive walking could be more likely to generate in areas with higher residential density via an indirect mechanism to create walkability.

- Improvement in land-use mix diversity: If residents could achieve multiple secondary purposes in addition to the primary purpose, their purposive walking frequency may decline. Land-use mix diversity comprises a horizontal mix formed by the diversity of land-use categories and a vertical mix formed by the diversity of building use categories. Hence, horizontal land-use mix formulated in a land-use plan and vertical building use mix regulated in zoning control can shape an environment of short distances between service facilities that ensures the availability of multiple purposes in a trip. With higher mixes for diversity, not only overall trips (Mahadevia \& Advani, 2016) but the demand for purposive walking trips could be reduced (Manoj \& Verma, 2016), as reported by the present study. In contrast, literature has suggested two opposite effects of diverse land use. That is, high land-use mixture with short distances between service facilities may be conducive to more purposive walks (Tian \& Ewing, 2017) but, simultaneously, may spare travelers the trips that would have occurred in a separate land-use environment because of achieving multiple purposes in fewer trips (Manoj \& Verma, 2016). The latter effect appears dominant in the present study so that the higher land-use mix diversity was, the higher purposive walking frequency was. In addition, the moderate conservation of historical and small buildings in land-use planning is also conducive to creating multiple service functions (Sung, Go, \& Choi, 2013) via varied rents accommodating different service operators (Jacobs, 1961).

- Improvement in land-use mix access: Transport system planning largely influences land-use mix access, but the practice of transport system planning must rely on the provision of needed lands by land-use plans. Thus, land-use plans for high land-use mix access should ensure the connection between multiple pedestrian paths and public transport stations. The connection could increase land-use mix access (Cerin et al., 2010) and be integrated into the TOD policy. Furthermore, the distribution of service facilities also influences land-use mix access. Land-use plans (designating land-use categories) and zoning control (designating building use categories in each land-use category) should accommodate service facility use surrounding and within 
residential blocks based on walking distance. As suggested by the present study, improving land-use mix access not only triggered more frequent purposive walking but more frequent and longer discursive walking. Since pedestrians may stay in spontaneous destinations during discursive walking, high accessibility to potential spontaneous destinations could induce nonpurposive walks.

- Improvement in street connectivity: If urban planning aims to shape a walkable city by high street connectivity, it is needed to avoid large-scale development blocks and form small blocks with high-density intersections in land-use plans (Southworth, 2005). Although both superblocks and small blocks can reduce vehicle speed and walking distances to daily services in the compact city concept, the latter create more intersections (Sung et al., 2013). Small-block landuse planning can be embodied in other urban development policies encouraging walking, such as transit-oriented development (TOD) (Calthorpe, 1993) and smart growth (Duany, Speck, \& Lydon, 2009). Furthermore, urban design guidelines should consider that street connectivity formation is not merely related to streets themselves but inner-block design. Firstly, pedestrian paths along roads should be achieved by providing floor-area-ratio incentives to create privately owned building setbacks in zoning control and regulating a minimum of building setbacks to create multiple alternatives of pedestrian paths or areas in urban design guidelines. Then, the guidelines, especially for large-scale blocks, should simultaneously regulate the conservation of inner-block public open space connecting the outer-block pedestrian paths to form a highconnectivity street network. These street connectivity improvement stratgies could promote both purposive and discursive walking.

- Improvement in aesthetics: Jacobs (1961) has presented that the mixture of "new" and "old and small" buildings in a district could create diverse and attractive street landscapes and activities during walking because the use of old and small buildings requests a lower rent. This viewpoint should be emphasized because urban renewals have been widely launched in urban areas, but urban sprawls, conflicting with urban renewal efforts, have still increased in urban surroundings in Taiwan. In the former, massive old and historical buildings have been demolished and threatened; in the latter, new and large-scale buildings have created many new towns with monotonous and fewer activities occurring along the streets. Both of the environments may discourage discursive walking. For creating environmental aesthetics, historical building conservation or reuse and diverse-scale land division for the coexistence of new/large-scale and old/small-scale buildings should be incorporated in land-use plans. Building height restrictions for ensuring skylines or mountain views and diverse use categories for on-street activity diversity should be considered in zoning control. In the hierarchy of urban design guidelines, the regulations of tree types harmonious with the environment, the number of tree-planting rows and the planting distance between trees along streets, and the rate of green coverage on sites could be applied to privately owned lands to improve environmental aesthetics.

- Improvement in pedestrian/traffic safety: The achievement of pedestrian/traffic safety appeals to regulating building setbacks as exclusive pedestrian sidewalks, controlling the locations and interfaces of building parking lot entrances/exits, and designating covered sidewalks free of rain in urban design guidelines. Moreover, at the land-use level, road space reallocation to increase pedestrian space and reduce on-street parking also improve safety. Such strategies improving pedestrian/traffic safety could reduce the required purposive walking time given a specific distance.

- Improvement in crime safety: Crime safety improvement may increase discursive walking frequency, and thus street lamps lighting at night at discursive walking paths and areas (e.g., near parks, schools, and residences) should be ensured. Particularly for privately owned large-scale building sites, street lamp distance/location and lighting time should be regulated by urban design guidelines. Also, informal surveillance provided by street and building users for each other, 
which is an effective means of criminal reduction (Jacobs, 1961), could be created by encouraging commercial use on the ground floor(s) in urban design guidelines and by diverse land and building use, respectively, in land-use plans and zoning control.

Table 7. Urban design strategies for environment walkability improvement

\begin{tabular}{|c|c|c|c|c|}
\hline \multicolumn{3}{|c|}{$\begin{array}{l}\text { Association of perceived environment walkability } \\
\text { (as target of urban design strategies) with walking }\end{array}$} & \multirow{2}{*}{$\begin{array}{l}\text { Mechanisms } \\
\text { inferred } \\
\text { Enough popula- } \\
\text { tion supporting } \\
\text { concentration of } \\
\text { facilities (indirect } \\
\text { mechanism) }\end{array}$} & \multirow{2}{*}{$\begin{array}{l}\begin{array}{l}\text { Corresponding urban design strategies for environment } \\
\text { walkability improvement }\end{array} \\
\text { Land-use plan for land-use category and zoning } \\
\text { control for floor area ratio to allocate appropriate } \\
\text { residential population }\end{array}$} \\
\hline $\begin{array}{l}\text { Increase in } \\
\text { residential density }\end{array}$ & $\rightarrow$ & $\begin{array}{l}\text { Increase in purposive } \\
\text { walking frequency and } \\
\text { duration }\end{array}$ & & \\
\hline $\begin{array}{l}\text { Improvement } \\
\text { in land-use mix } \\
\text { diversity }\end{array}$ & $\rightarrow$ & $\begin{array}{l}\text { Decrease in purposive } \\
\text { walking frequency }\end{array}$ & $\begin{array}{l}\text { Availability of multi- } \\
\text { purposes in a trip }\end{array}$ & $\begin{array}{l}\text { - Land-use plan for conservation of old and small } \\
\text { buildings with low rents to create multiple functions } \\
\text { Land-use plan for horizontal mix of land-use catego- } \\
\text { ries } \\
\text { zoning control for vertical mix of building-use } \\
\text { categories }\end{array}$ \\
\hline $\begin{array}{l}\text { Improvement } \\
\text { in land-use mix } \\
\text { access }\end{array}$ & $\rightarrow$ & $\begin{array}{l}\text { (1) Increase in purposive } \\
\text { walking frequency } \\
\text { (2) Increase in discursive } \\
\text { walking duration and } \\
\text { frequency }\end{array}$ & $\begin{array}{l}\text { (1) Convenience of } \\
\text { walking to premedi- } \\
\text { tated destinations } \\
\text { (2) Convenience of } \\
\text { walking to spontane- } \\
\text { ous destinations }\end{array}$ & $\begin{array}{l}\text { Transport system planning (reflected in land use } \\
\text { plans) for connection between multiple pedestrian } \\
\text { paths and public transport stations. } \\
\text { Land use plans and zoning control for walking- } \\
\text { distance-based layout of service facilities. }\end{array}$ \\
\hline $\begin{array}{l}\text { Improvement in } \\
\text { street connectivity }\end{array}$ & $\rightarrow$ & $\begin{array}{l}\text { (1) Increase in purposive } \\
\text { walking duration } \\
\text { (2) Increase in discursive } \\
\text { walking frequency }\end{array}$ & $\begin{array}{l}\text { (1) Less constraint } \\
\text { by spatial distance } \\
\text { (2) Simultaneity of } \\
\text { discursive walking } \\
\text { with other purposes }\end{array}$ & $\begin{array}{l}\text { - Land-use plan for small blocks with high-density } \\
\text { intersections } \\
\text { - Zoning control providing floor-area-ratio incentives } \\
\text { to create building setbacks for pedestrians } \\
\text { - Urban design guidelines for building setbacks to cre- } \\
\text { ate multiple paths or areas for pedestrians }\end{array}$ \\
\hline $\begin{array}{l}\text { Improvement in } \\
\text { aesthetics }\end{array}$ & $\rightarrow$ & $\begin{array}{l}\text { Increase in discursive } \\
\text { walking duration and } \\
\text { frequency }\end{array}$ & $\begin{array}{l}\text { Attractiveness from } \\
\text { diverse streetscapes } \\
\text { and street activities }\end{array}$ & $\begin{array}{l}\text { Land-use plans incorporating historical building } \\
\text { conservation or reuse and diverse-scale land division } \\
\text { for coexistence of new/large-scale and old/small-scale } \\
\text { buildings } \\
\text { - Zoning control considering building height restric- } \\
\text { tions for ensuring skylines or mountain views and } \\
\text { diverse use categories for on-street activity diversity } \\
\text { Urban design guidelines regulating line number and } \\
\text { planting distance of street trees and green coverage } \\
\text { rate of sites }\end{array}$ \\
\hline $\begin{array}{l}\text { Improvement in } \\
\text { pedestrian/traffic } \\
\text { safety }\end{array}$ & $\rightarrow$ & $\begin{array}{l}\text { Decrease in purposive } \\
\text { walking duration }\end{array}$ & $\begin{array}{l}\text { Time-saving for } \\
\text { pedestrian passage } \\
\text { by excluding } \\
\text { interference }\end{array}$ & $\begin{array}{l}\text { - Transport system planning (reflected in land-use plan) } \\
\text { for road space reallocation to increase pedestrian space } \\
\text { and reduce on-street parking } \\
\text { - Urban design guidelines for building setbacks as } \\
\text { exclusive pedestrian sidewalks } \\
\text { - Urban design guidelines for controlling locations and } \\
\text { interfaces of building parking lot entrances/exits } \\
\text { Urban design guidelines for designating covered } \\
\text { sidewalks free of raining }\end{array}$ \\
\hline $\begin{array}{l}\text { Improvement in } \\
\text { crime safety }\end{array}$ & $\rightarrow$ & $\begin{array}{l}\text { Increase in discursive } \\
\text { walking frequency }\end{array}$ & $\begin{array}{l}\text { Safety perception } \\
\text { of streets as activity } \\
\text { places }\end{array}$ & $\begin{array}{l}\text { - Land-use plan and zoning control for diverse land and } \\
\text { building use } \\
\text { - Urban design guidelines for street lamp distance/loca- } \\
\text { tion and lighting time } \\
\text { - Urban design guidelines for ground-floor commercial } \\
\text { use to create informal surveillance }\end{array}$ \\
\hline
\end{tabular}




\section{Conclusion and discussion}

\subsection{Summary of findings}

This study identified the association of PEW with walking frequency and duration among Taiwanese, which differed between walking to a destination (purposive walking) and walking as an activity purpose (discursive walking). Purposive walking was positively associated with residential density (in frequency and duration), land-use mix access (in frequency), and street connectivity (in duration), whereas it was negatively associated with land-use mix diversity (in frequency) and pedestrian/traffic safety (in frequency and duration). Differently, discursive walking duration was positively associated with land-use mix access and aesthetics; in addition to the two environmental factors, street connectivity and crime safety were positive correlates of discursive walking frequency. Based on these findings, this study explored how to apply urban design tools, including land-use plans, zoning control, and urban design guidelines, to create a walkable environment.

Regarding the contribution to the related literature, by differentiating purposive and discursive walking, this study provided a refined understanding of the relationship between the built environment and walking behavior and thus elaborated on urban design strategies for the walkability of the two types of walkers. However, several remaining issues should be further addressed, including the correlated factors of walking whose influence mechanisms were challenging to clarify, the role of walkability in transport planning, the need for more sophisticated approaches to investigating environment-walking associations, and unclarified diverse walking behavior related to how to define and improve walkability. Thus, the work undertaken by the present study and the remaining issues are discussed as follows.

\subsection{Future recommendations}

(1) Further investigation into correlates of walking

Purposive walking frequency was found to be negatively correlated with pedestrian/traffic safety. This phenomenon implied that residents may have a higher demand for purposive trips, consequently generating more purposive walks, in prosperous environments with lower pedestrian/traffic safety. The mechanism behind the phenomenon and the pedestrian safety of residents with frequent purposive walks should be discussed in future research. In addition, shorter discursive walking duration occurred in environments with a higher level of walking facilities. This outcome was probably because discursive pedestrians may not consider walking facilities to decide walking duration or because they may intend to avoid crowded commuting walking areas with walking infrastructure in good condition. However, what is the mechanism should be further examined. Moreover, a higher level of physical obstruction was accompanied by higher discursive walking frequency, implying that discursive walking demands may be more likely to emerge in prosperous environments with more interference from other road users such as vendors and parked vehicles. Hence, the influence of physical obstruction on the quality of discursive walking is needed to be investigated.

(2) Role of walkability in transport planning

Although this study revealed the associations between PEW and two types of walking behavior, the models did not exhibit an impressive model fit. This outcome may be because perceiving the environment as walkable is not a sufficient condition for walking behavior. According to a conceptual framework integrating neighborhood environment into walk trip generation models (Tian \& Ewing, 2017), 
accurately accounting for walking behavior may also entail land use (e.g., population density and jobpopulation balance) and household and individual socio-demographics (e.g., household size, children number, employment, driving license possession, and income) (Habib et al., 2014; Olojede et al., 2017; Tian \& Ewing, 2017). Unfortunately, little empirical research has completely integrated those factors because of difficulty in identifying objective neighborhood environments varying across individuals in different neighborhoods or even in the same one for large-scale quantitative individual-level data collection. For an ideal example where objective neighborhood environment features across individuals are obtained, each individual's activity area is first defined (by face-to-face interview or GPS-devicebased activity survey). Then, the objective feature data of the environment specific to the individual are collected. However, it costs massively to do so for all individuals in a large sample size. Instead, prior research has often ignored neighborhood environments (Habib et al., 2014) or substituted the objective neighborhood environments beyond those perceived by individuals (Tian \& Ewing, 2017). In contrast, the factors of perceived neighborhood environments built by the present study based on the NEWS could accommodate individual responses to objective neighborhood environments in walkability, including land-use diversity and accessibility. Thus, these environmental factors could complement walk trip generation models, such as incorporating their factor scores into predictors, especially for the factors associated with purposive walking. For future research, PEW data collection needs to be embodied in large-scale household travel surveys where household and individual socio-demographics can be completely obtained to refine general and walking trip generation models for travel demand forecasting and transport planning.

(3) Causality between PEW and walking behavior

This study examined the associations between PEW and walking behavior, but their causality cannot be conclusively inferred. Future research on walking generation mechanisms should compare walking behavior between districts with heterogeneous environment walkability. By contrast, if using longitudinal data, a social experiment implementing interventions in PEW could provide firm evidence for the causality between the PEW factors of interest and walking behavior. However, social experiments entail high costs and difficulty in controlling extraneous factors. As a compromise method, quasi-longitudinal design defines experimental treatment as a move from one neighborhood to another with accounting for preferences and attitudes that might affect neighborhood choice, supporting the causal relationship between a change in the built environment and a change in driving (Handy, Cao, \& Mokhtarian, 2005). This method can also be applied to investigating the causal mechanism behind PEW-walking associations to benefit the development of walkable environments.

(4) Anatomy of diverse types of walking behavior

This study contributed to a more refined relationship between environment walkability and walking behavior by differentiating purposive and discursive walking, which is beneficial to urban design strategies for different types of pedestrians. Furthermore, the association of environment walkability with purposive walking can provide insight into transport planning and travel demand management, reducing private vehicle use because purposive walking travel is substituted for private vehicle travel. By contrast, the understanding regarding discursive walking can benefit open place planning and street vitality improvement because discursive pedestrians are not concerned, at least when deciding to walk, about efficient movement from place to place but consider expected perceptions during walking. However, to incorporate heterogeneous walkability into formal policy measures, future research should deeply analyze the multiple roles of walking behavior and link them with policy evaluation. In cities, diverse types of walking behavior that have been qualitatively identified, such as "conceptual walking" involving 
a means of obtaining knowledge regarding a city (Wunderlich, 2008), "exercise walking” with a pure health reason (Humpel, Owen, Iverson, Leslie, \& Bauman, 2004), “combination walking” including destination and strolling purposes in one journey (Alfonzo, 2005), and "interserial walking" that features ongoing transformations in different types of walking by recognizing boundary objects, which ultimately produce a mutable but sustaining walking person (Kärrholm et al., 2014). The anatomy of these plural features of walking behavior, instead of regarding walking behavior as a mere travel mode of "transport on foot" in conventional transport planning or a single activity of "walking" in activity-based travel demand analysis, will be conducive to defining in detail what is walkability and thereby formulating more sophisticated walkable environment strategies for diverse pedestrians.

\subsection{Conclusion}

The associations of perceived neighborhood environment with walking frequency and duration differed between purposive and discursive walks. Urban planners or designers should grasp the difference to shape the built environment to promote walking. For a solid planning ground, in addition to this and prior studies, the following steps must include further investigations into the determinants of walking, practical applications of PEW data to trip generation models for travel demand forecasting and transport planning, examinations of the causal relationship between the built environment and walking behavior, and quantifying qualitatively identified diverse walking types for the environment-walking association. Creating walkable environments with public health and sustainable development would benefit from these efforts.

\section{Acknowledgements}

The author thanks the grant from the Ministry of Science and Technology, Taiwan (MOST 108-2628-H110-007-SSS). 


\section{References}

Alfonzo, M. A. (2005). To walk or not to walk? The hierarchy of walking needs. Environment and Behavior, 37(6), 808-836. https://doi:10.1177/0013916504274016

Anderson, J. C., \& Gerbing, D. W. (1988). Structural equation modeling in practice: A review and recommended two-step approach. Psychological Bulletin, 103(3), 411.

Brownson, R. C., Chang, J. J., Eyler, A. A., Ainsworth, B. E., Kirtland, K. A., Saelens, B. E., \& Sallis, J. F. (2004). Measuring the environment for friendliness toward physical activity: A comparison of the reliability of 3 questionnaires. American Journal of Public Health, 94(3), 473-483. https:// doi:10.2105/ajph.94.3.473

Burbidge, S., \& Goulias, K. (2009). Active travel behavior. Transportation Letters, 1(2), 147-167. https://doi:10.3328/TL.2009.01.02.147-167

Calthorpe, P. (1993). The next American metropolis: Ecology, community, and the American dream. New York: Princeton Architectural Press.

Careri, F. (2017). Walkscapes: Walking as an aesthetic practice. Ames, IA: Culicidae Architectural Press.

Cerin, E., Macfarlane, D. J., Ko, H. H., \& Chan, K. C. A. (2007). Measuring perceived neighborhood walkability in Hong Kong. Cities, 24, 209-217. https://doi:10.1016/j.cities.2006.12.002

Cerin, E., Saelens, B. E., Sallis, J. F., \& Frank, L. D. (2006). Neighborhood environment walkability scale: Validity and development of a short form. Medicine and Science in Sports and Exercise, 38, 1682-1691. https://doi:10.1249/01.mss.0000227639.83607.4d

Cerin, E., Sit, C. H. P., Cheung, M. C., Ho, S. Y., Lee, L. C. J., \& Chan, W. M. (2010). Reliable and valid NEWS for Chinese seniors: Measuring perceived neighborhood attributes related to walking. International Journal of Behavioral Nutrition and Physical Activity, 7(1), 84.

Chang, H. L., \& Shen, Y. C. (2005). People's intention to walk-a case study for Taipei citizens. Journal of the Chinese Institute of Transportation, 17, 233-260. https://doi:10.6383/JCIT.200509.0233

Chiang, Y. C., \& Weng, P. Y. (2012). More walking and healthier living: The relationship between walkable environments and residents' health. Journal of Outdoor Recreation Study, 25, 25-50. https:// doi:10.6130/JORS.2012.25(4)2

Chou, Y. H., Wang, S. Y. B., \& Lin, Y. T. (2019). Long-term care and technological innovation: The application and policy development of care robots in Taiwan. Journal of Asian Public Policy, 12(2) 1-20. https://doi:10.1080/17516234.2018.1492315

Craig, C. L., Marshall, A. L., Sjöström, M., Bauman, A. E., Booth, M. L., Ainsworth, B. E., . . Oja, P. (2003). International physical activity questionnaire: 12 -country reliability and validity. Medicine and Science in Sports and Exercise, 35(8) 1381-1395. https://doi:10.1249/01.MSS.0000078924.61453. FB

De Bourdeaudhuij, I., Sallis, J. F., \& Saelens, B. E. (2003). Environmental correlates of physical activity in a sample of Belgian adults. American Journal of Health Promotion, 18, 83-92. https:// doi:10.4278/0890-1171-18.1.83

Duany, A., Speck, J., \& Lydon, M. (2009). The smart growth manual. New York: McGraw-Hill Professional.

Ewing, R., \& Handy, S. (2009). Measuring the unmeasurable: Urban design qualities related to walkability. Journal of Urban Design, 14(1), 65-84. https://doi:10.1080/13574800802451155

Gase, L. N., Barragan, N. C., Simon, P. A., Jackson, R. J., \& Kuo, T. (2015). Public awareness of and support for infrastructure changes designed to increase walking and biking in Los Angeles County. Preventive Medicine, 72, 70-75. https://doi:10.1016/J.YPMED.2014.12.033

Greenwald, M. J., \& Boarnet, M. G. (2001). Built environment as determinant of walking behavior- 
Analyzing nonwork pedestrian travel in Portland, Oregon. Transportation Research Record, 1780(1), 33-41. https://doi.org/10.3141/1780-05

Habib, K. N., Han, X., \& Lin, W. H. (2014). Joint modelling of propensity and distance for walkingtrip generation. Transportmetrica a-Transport Science, 10(5), 420-436. https://doi:10.1080/232499 35.2013 .778356

Handy, S., Cao, X., \& Mokhtarian, P. (2005). Correlation or causality between the built environment and travel behavior? Evidence from Northern California. Transportation Research Part D: Transport and Environment, 10(6), 427-444. https://doi:10.1016/j.trd.2005.05.002

Hsieh, H. S. (2020). Transport policy evaluation based on elasticity analysis with social interactions. Transportation Research Part A: Policy and Practice, 139, 273-296. https://doi:10.1016/j.tra.2020.07.011

Humpel, N., Owen, N., Iverson, D., Leslie, E., \& Bauman, A. (2004). Perceived environment attributes, residential location, and walking for particular purposes. American Journal of Preventive Medicine, 26(2), 119-125. https://doi:10.1016/j.amepre.2003.10.005

Inoue, S., Ohya, Y., Odagiri, Y., Takamiya, T., Ishii, K., Kitabayashi, M., . . Shimomitsu, T. (2010). Association between perceived neighborhood environment and walking among adults in 4 cities in Japan. Journal of Epidemiology, 20(4), 277-286. https://doi:10.2188/jea.JE20090120

Inoue, S., Ohya, Y., Odagiri, Y., Takamiya, T., Ishii, K., Lee, J. S., \& Shimomitsu, T. (2009). Reliability of the abbreviated neighborhood environment walkability scale Japanese version. Japanese Journal of Physical Fitness and Sports Medicine, 58, 453-462. https://doi:10.7600/jspfsm.58.453

ITE. (2017). Trip generation (10th Edition ed.). Washington, DC: Institute of Transportation Engineers. Jacobs, J. (1961). The death and life of great American cities. New York: Random House.

Kaczynski, A. T., Besenyi, G. M., Child, S., Morgan Hughey, S., Colabianchi, N., McIver, K. L., \& Dowda, R. R. (2018). Relationship of objective street quality attributes with youth physical activity: Findings from the Healthy Communities Study. Pediatric Obesity, 13(Suppl 1), 7-13. https:// doi:10.1111/ijpo.12429

Kerr, J., Rosenberg, D., Sallis, J. F., Saelens, B. E., Frank, L. D., \& Conway, T. L. (2006). Active commuting to school: Associations with environment and parental concerns. Medicine and Science in Sports and Exercise, 38, 787-794. https://doi:10.1249/01.mss.0000210208.63565.73

Kärrholm, M., Johansson, M., Lindelöw, D., \& Ferreira, I. A. (2014). Interseriality and different sorts of walking: Suggestions for a relational approach to urban walking. Mobilities, 12(1), 20-35. https:// doi:10.1080/17450101.2014.969596

Leslie, E., \& Cerin, E. (2008). Are perceptions of the local environment related to neighborhood satisfaction and mental health in adults? Preventive Medicine, 47, 273-278. https://doi:10.1016/j. ypmed.2008.01.014

Li, S., Zhao, P., Zhang, H., \& Quan, J. (2019). Walking behavior in the old downtown Beijing: The impact of perceptions and attitudes and social variations. Transport Policy, 73, 1-11. https:// doi:10.1016/J.TRANPOL.2018.10.005

Longo, A., Hutchinson, W. G., Hunter, R. F., Tully, M. A., \& Kee, F. (2015). Demand response to improved walking infrastructure: A study into the economics of walking and health behavior change. Social Science \& Medicine, 143, 107-116. http://doi:10.1016/J.SOCSCIMED.2015.08.033

Mahadevia, D., \& Advani, D. (2016). Gender differentials in travel pattern - The case of a mid-sized city, Rajkot, India. Transportation Research Part D: Transport and Environment, 44, 292-302. https:// doi.org/10.1016/j.trd.2016.01.002

Manoj, M., \& Verma, A. (2016). Effect of built environment measures on trip distance and mode choice decision of non-workers from a city of a developing country, India. Transportation Research Part D: Transport and Environment, 46, 351-364. https://doi.org/10.1016/j.trd.2016.04.013 
MOTC. (2017). 2016 daily travel mode use survey. Taiwan: Ministry of Transportation and Communications of Taiwan.

Olojede, O., Yoade, A., \& Olufemi, B. (2017). Determinants of walking as an active travel mode in a Nigerian city. Journal of Transport \& Health, 6(Supplement C), 327-334. https://doi.org/10.1016/j. jth.2017.06.008

Saelens, B. E., Sallis, J. F., Black, J. B., \& Chen, D. (2003). Neighborhood-based differences in physical activity: An environment scale evaluation. American Journal of Public Health, 93, 1552-1558.

Saelens, B. E., Sallis, J. F., \& Frank, L. D. (2003). Environmental correlates of walking and cycling: Findings from the transportation, urban design, and planning literatures. Annals of Behavioral Medicine, 25(2), 80-91.

Sallis, J. F., Johnson, M. F., Calfas, K. J., Caparosa, S., \& Nichols, J. F. (1997). Assessing perceived physical environmental variables that may influence physical activity. Research Quarterly for Exercise and Sport, 68, 345-351. https://doi:10.1080/02701367.1997.10608015

Sarmento, J. (2016). Tourists' walking rhythms: 'Doing' the Tunis Medina, Tunisia. Social \& Cultural Geography, 18(3), 295-314. https://doi:10.1080/14649365.2016.1174283

Shevlin, M., Miles, J. N. V., Davies, M. N. O., \& Walker, S. (2000). Coefficient alpha: A useful indicator of reliability? Personality and Individual Differences, 28(2), 229-237. https://doi:10.1016/s01918869(99)00093-8

Southworth, M. (2005). Designing the walkable city. Journal of Urban Planning and Development, 131(4), 246. https://doi:10.1061/(ASCE)0733-9488(2005)131:4(246)

Sung, H.-G., Go, D.-H., \& Choi, C. G. (2013). Evidence of Jacobs's street life in the great Seoul city: Identifying the association of physical environment with walking activity on streets. Cities, 35, 164-173. https://doi:10.1016/j.cities.2013.07.010

Taber, K. S. (2018). The use of Cronbach's alpha when developing and reporting research instruments in science education. Research in Science Education, 48(6), 1273-1296. https://doi:10.1007/s11165016-9602-2

Tian, G., \& Ewing, R. (2017). A walk trip generation model for Portland, OR. Transportation Research Part D: Transport and Environment, 52(Part A), 340-353. https://doi.org/10.1016/j.trd.2017.03.017

Tung, C.-M. (2005). The study of influential factors of pedestrian space choice in Taipei Shi-Men pedestrian mall. Journal of Chia Institute of Technology, 101-113. https://doi:10.7095/JCIT.200505.0101

Winkler, J. (2002). Working on the experience of passing environments: On commented walks. In J. Winkler (Ed.), Space, sound and time: A choice of articles on soundscape studies and aesthetics of environment 1990-2000. Basel, Switzerland: University of Basel.

Wunderlich, F. M. (2008). Walking and rhythmicity: Sensing urban space. Journal of Urban Design, 13(1), 125-139. https://doi:10.1080/13574800701803472

Yang, Y., Xu, Y., Rodriguez, D. A., Michael, Y., \& Zhang, H. (2018). Active travel, public transportation use, and daily transport among older adults: The association of built environment. Journal of Transport \& Health, 9, 288-298. https://doi:10.1016/J.JTH.2018.01.012

Yu, R., Cheung, O., Lau, K., \& Woo, J. (2017). Associations between perceived neighborhood walkability and walking time, wellbeing, and loneliness in community-dwelling older Chinese people in Hong Kong. International Journal of Environmental Research and Public Health, 14(10), 1199. https://doi:10.3390/ijerph14101199 